\title{
EXO1-dependent single-stranded DNA at telomeres activates subsets of DNA damage and spindle checkpoint pathways in budding yeast yku70s mutants
}

\author{
Laura Maringele and David Lydall ${ }^{1}$ \\ School of Biological Sciences, University of Manchester, Manchester M13 9PT, UK
}

\begin{abstract}
We have examined the role of checkpoint pathways in responding to a yku70د defect in budding yeast. We show that CHK1, MEC1, and RAD9 checkpoint genes are required for efficient cell cycle arrest of yku70D mutants cultured at $37^{\circ} \mathrm{C}$, whereas $R A D 17, R A D 24, M E C 3, D D C 1$, and DUN1 play insignificant roles. We establish that cell cycle arrest of yku70D mutants is associated with increasing levels of single-stranded DNA in subtelomeric $\mathrm{Y}^{\prime}$ regions, and find that the mismatch repair-associated EXO1 gene is required for both ssDNA generation and cell cycle arrest of $y k u 70 \Delta$ mutants. In contrast, MRE11 is not required for ssDNA

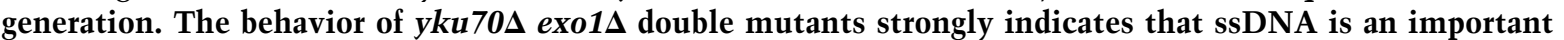
component of the arrest signal in yku70s mutants and demonstrates a link between damaged telomeres and mismatch repair-associated exonucleases. This link is confirmed by our demonstration that EXO1 also plays a role in ssDNA generation in $c d c 13-1$ mutants. We have also found that the MAD2 but not the BUB2 spindle checkpoint gene is required for efficient arrest of yku70د mutants. Therefore, subsets of both DNA-damage and spindle checkpoint pathways cooperate to regulate cell division of $y k u 70 \Delta$ mutants.
\end{abstract}

[Key Words: Checkpoint; telomere; KU; EXO1; CDC13; ssDNA]

Received January 10, 2002; revised version accepted June 6, 2002.

The telomere is a DNA-protein complex at the end of eukaryotic chromosomes. If telomeric DNA, which has many properties of a double strand break (DSB), was perceived as a DSB by DNA repair machinery and underwent recombination, then harmful telomere fusions and dicentric chromosomes would be generated. Similarly, if telomeric DNA were perceived as a DSB by DNA damage checkpoint machinery, it would be harmful, because in budding yeast a single unrepaired DSB elsewhere in the genome can inhibit cell cycle progression for many generation times (Sandell and Zakian 1993). Therefore, it is essential for chromosome stability and cell cycle progression that telomeres hide the DSB-like structures that they contain. An important function of some of the large number of telomere binding proteins, such as Cdc13p (essential in budding yeast) and Ku70/Ku80 heterodimer (conserved from yeast to mammalian cells), is to hide telomeric DNA from repair and checkpoint pathways.

Budding yeast mutants defective in telomere binding proteins are useful tools to address the mechanisms by

${ }^{1}$ Corresponding author.

E-MAIL lydall@man.ac.uk; FAX 44-0-161-275-5600.

Article and publication are at http://www.genesdev.org/cgi/doi/10.1101/ $\operatorname{gad} .225102$. which checkpoint pathways recognize damaged DNA, because in these cells telomeres become potent activators of DNA damage checkpoint pathways in a conditional manner. For example, at $23^{\circ} \mathrm{C}$, a permissive temperature for cdc13-1 mutants, telomeres are not recognized as damaged DNA, but at $36^{\circ} \mathrm{C}$ temperatures, they are potent activators of cell cycle arrest (Weinert and Hartwell 1993). Cell cycle arrest of $c d c 13-1$ mutants is associated with accumulation of single-stranded DNA (ssDNA) at telomeres (Garvik et al. 1995). Furthermore, not only do checkpoint pathways recognize cdc13-1-induced damage, but they also affect the rate at which ssDNA arises (Lydall and Weinert 1995).

The Ku heterodimer is an evolutionarily conserved protein complex involved in the nonhomologous endjoining (NHEJ) pathway of DNA repair (Smith and Jackson 1999). Interestingly and paradoxically, the Ku heterodimer is important for telomere stability. For example, there is evidence that the $\mathrm{Ku}$ heterodimer protects mammalian chromosomes from telomere fusions (Bailey et al. 1999; Hsu et al. 2000; Samper et al. 2000; d'Adda di Fagagna et al. 2001). In one study, $62 \%$ of $\mathrm{ku} 8 \mathrm{O}^{-/-}$mouse embryonal fibroblasts contained telomere fusions, a level 30 times higher than that seen in Ku-proficient fibroblasts (Hsu et al. 2000).

The budding yeast homolog of the $\mathrm{Ku}$ heterodimer is 
the Yku70p/Yku80p heterodimer. Mutants with deletions of YKU70 or YKU80 contain short telomeres (Boulton and Jackson 1996, 1998; Porter et al. 1996), have single-stranded DNA (ssDNA) in their repetitive telomeric TG sequences (Gravel et al. 1998; Polotnianka et al. 1998), display decreased telomeric silencing (Boulton and Jackson 1998; Mishra and Shore 1999; Pryde and Louis 1999), and altered telomere localization (Laroche et al. 1998). Furthermore, there is evidence that the KU heterodimer is able to bind to the telomerase RNA directly (Peterson et al. 2001) and is localized at telomeres (Martin et al. 1999).

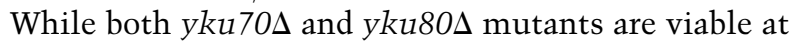
permissive temperatures such as $30^{\circ} \mathrm{C}$, they are unable to form colonies at $37^{\circ} \mathrm{C}$ (Feldmann and Winnacker 1993; Barnes and Rio 1997). This temperature-sensitive phenotype appears to be due specifically to a telomere defect, rather than a more generalized DNA repair defect, because the temperature-sensitive phenotype can be partially suppressed by overexpression of telomerase subunits (Nugent et al. 1998; Teo and Jackson 2001; Lewis et al. 2002) or rarely $\left(1 \times 10^{-7} /\right.$ cell $)$ by amplification of subtelomeric repeats (Fellerhoff et al. 2000). By combining the yku70s mutation with checkpoint mutations and culturing the cells at high temperatures, we have been able to examine the role of different checkpoint genes in responding to (sub) telomeric defects in yku70s mutants.

Checkpoint pathways consist of proteins that interact with damaged DNA and signal transduction cascades that inhibit cell division (Lowndes and Murguia 2000; Caspari and Carr 2002). Here we show that some, but not all DNA damage checkpoint genes contribute to the inhibition of cell division of yku70s mutants. Interestingly, a subset of spindle checkpoint pathways also contributes to arrest. Furthermore, there is a correlation between cell cycle arrest and the accumulation of ssDNA in subtelomeric sequences in yku70s mutants. Finally, we show that the mismatch repair-associated exonuclease EXO1 is essential for ssDNA generation in yku70 mutants, while MRE11 is not, and that EXO1 is also required to generate ssDNA in $c d c 13-1$ mutants.

\section{Results}

CHK1, MEC1, and RAD9 are required

for a yku70s-induced checkpoint

To determine how checkpoint pathways interact with yku70 -induced damage in budding yeast, we generated a panel of double and triple mutants. Weinert and Hartwell showed previously that checkpoint mutations allow cdc13-1 mutant strains, defective in a telomere binding protein, to form colonies at higher temperatures than checkpoint-proficient cdc13-1 strains (Weinert and Hartwell 1993; Weinert et al. 1994). This is presumably because loss of checkpoint control allows cells with nonlethal levels of DNA damage to divide and form colonies. Figure 1 shows the growth of serial dilutions of yku70s and checkpoint mutant cells at $28^{\circ} \mathrm{C}, 36^{\circ} \mathrm{C}$, and $37^{\circ} \mathrm{C}$. At $28^{\circ} \mathrm{C}$, a permissive temperature for yku70s mutants, all strains grew at similar rates and formed similarly sized colonies. At the restrictive temperatures of $36^{\circ} \mathrm{C}$ and $37^{\circ} \mathrm{C}$, different strains formed colonies with different efficiencies. A chk $1 \Delta$ mutation had the most profound effect and significantly increased the ability of yku70s mutants to form colonies at both $36^{\circ} \mathrm{C}$ and $37^{\circ} \mathrm{C}$ (Fig. $1 \mathrm{~g}-\mathrm{i})$. rad $9 \Delta$ and mec1s also increased yku70s colony size, but the colonies were smaller than the yku70s $\operatorname{chk} 1 \Delta$ colonies (Fig. 1d-i). In contrast, mec3s, ddc1s, $\operatorname{rad} 17 \Delta, \operatorname{rad} 24 \Delta$, and dun $1 \Delta$ mutations had minor effects on the growth of yku70s mutants (Fig. 1a-i). The growth

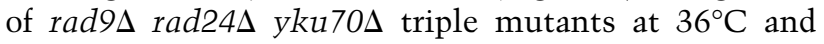
$37^{\circ} \mathrm{C}$ was most similar to that of yku $70 \Delta$ rad $9 \Delta$ mutants, indicating that the strong growth phenotype was epistatic (Fig. 1d-f). These experiments suggested that a $C H K 1, M E C 1$, and RAD9-dependent, but DDC1, MEC3, $R A D 17, R A D 24$, and DUN1-independent mechanism is responsible for the poor growth of yku70s mutants at $36^{\circ} \mathrm{C}$ and $37^{\circ} \mathrm{C}$.

To determine whether checkpoint pathways are activated in yku70s mutants, we examined the growth and cell cycle distribution of yku70s and checkpoint mutants in liquid cultures (Fig. 2). In four separate experi-

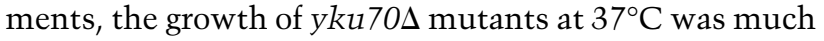
slower than $Y K U 70^{+}$cells, such that by $8.5 \mathrm{~h}$ their cell number had increased about 4-8-fold, instead of 80-100fold as observed in the $Y K U 70^{+}$cells (Fig. $2 \mathrm{a}-\mathrm{d}$ ). In addition, in three of four experiments, the growth of yku70s cells began to plateau after about $6 \mathrm{~h}$ in liquid culture (Fig. 2a-d; data not shown). The poor growth of yku70s mutants correlates with an increasing fraction of cells at the medial nuclear division stage of the cell cycle (Hartwell 1974), increasing from $\sim 20 \%$ at the beginning of the experiments, to over $85 \%$ during $8.5 \mathrm{~h}$ culture at $37^{\circ} \mathrm{C}$ (Fig. 2e-h). This accumulation of cells at medial nuclear division suggests they are accumulating before the metaphase/anaphase transition, and is consistent with an earlier study which showed that the large budded cells that accumulated in yku70s (hdf1s) mutant cultures at $37^{\circ} \mathrm{C}$ contained short mitotic spindles and a nucleus at the neck between the mother and daughter cells (Barnes and Rio 1997). The slow kinetics of arrest of yku70s mutants is in contrast to the behavior of $c d c 13-1$ mutants, because $94 \%$ of $c d c 13-1$ mutants arrest in the first cell cycle (within $2 \mathrm{~h}$ ) at restrictive temperature (Weinert and Hartwell 1993).

At $37^{\circ} \mathrm{C}$, the growth and cell cycle distribution of

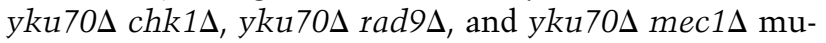
tants was most like $Y K U 70^{+} R A D^{+}$strains because they grew exponentially and did not accumulate at medial nuclear division (Fig. 2c, d,g,h; data not shown). Therefore, it appears that the poor growth of yku70s mutants at $37^{\circ} \mathrm{C}$ and the accumulation in medial nuclear division is due to a CHK1, MEC1, and RAD9-dependent checkpoint pathway. In contrast, the growth and cell cycle distributions of yku70s ddc1s, yku70s rad24, and yku70s dun1s mutants were most similar to yku70s

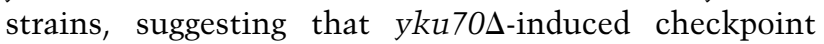
pathways are intact in rad24 $\Delta, d d c 1 \Delta$, and dun $1 \Delta$ mutants (Fig. 2a,b,e,f). Both yku70s mec3s and yku70s 


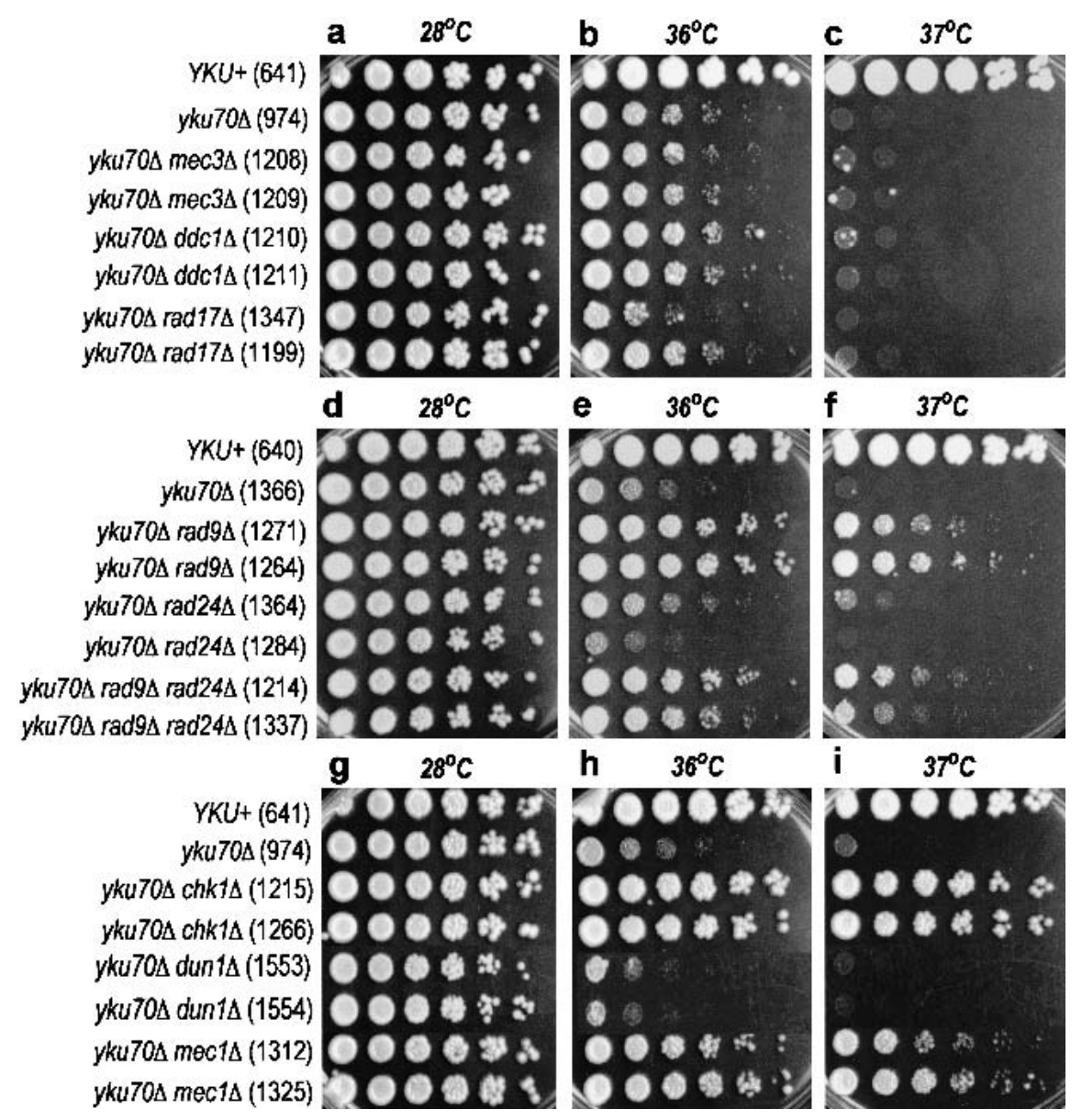

Figure 1. $R A D 9, M E C 1$, and $C H K 1$ inhibit growth of yku70s strains at high temperatures. Small aliquots of fivefold dilution series of several yeast strains were transferred to plates and incubated at the temperatures indicated for $2 \mathrm{~d}$ before being photographed. The relevant genotypes of the strains are indicated on the left, and the strain numbers shown in parentheses. The mec1s strains also carried an sml1s mutation. To ensure reproducibility we routinely examined two independent strains with the same genotypes. All strains grouped together were grown on the same plates, except for the

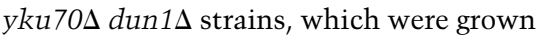
on different plates. The photographs of

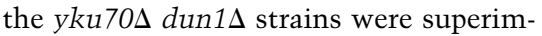
posed in $g, h, i$.

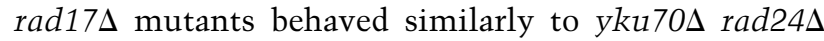
mutants (data not shown). We found that rad53 $\Delta \mathrm{sml1 \Delta}$ single mutants, as well as yku70 $\mathrm{rad} 53 \Delta \mathrm{sml1 \Delta}$ triple mutants grew poorly in liquid culture at $37^{\circ} \mathrm{C}$, which made it difficult to determine the role of $R A D 53$ in cell cycle arrest (data not shown). This may be because $R A D 53$ has an essential function at $37^{\circ} \mathrm{C}$ that is unrelated to checkpoint control (Gardner et al. 1999; Sanchez et al. 1999).

We noted that, despite their initial checkpoint defective phenotype, yku70s mec1s and yku70s chk1s mutants begin to slow cell division and start to accumulate at medial nuclear division, after long periods $(8 \mathrm{~h})$ at $37^{\circ} \mathrm{C}$ (Fig. $2 \mathrm{c}, \mathrm{d}, \mathrm{g}, \mathrm{h}$ ). This suggests that another checkpoint pathway, independent of CHK1 and MEC1, can arrest cell division of $y k u 70 \Delta$ mutants after long periods at $37^{\circ} \mathrm{C}$. This arrest is due to the activation of spindle checkpoint pathways (see Fig. 4, below). Both yku70s rad $24 \Delta$ rad $9 \Delta$ and yku $70 \Delta$ rad $24 \Delta$ mec $1 \Delta$ triple mutants

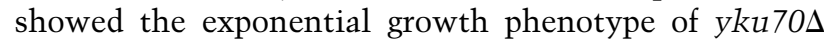

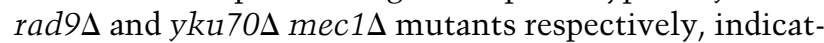
ing that the exponential growth phenotype is epistatic to the poor growth phenotype (Fig. $2 \mathrm{~d}$,h; data not shown). In summary, these liquid culture experiments suggest that a checkpoint pathway that arrests yku70s mutants at medial nuclear division at $37^{\circ} \mathrm{C}$ is dependent on $C H K 1$,
RAD9, and MEC1, but independent of RAD17, RAD24, $M E C 3, D D C 1$, and DUN1.

Microcolony assays were used to confirm that yku70s mutants are able to divide several times before ceasing growth at $37^{\circ} \mathrm{C}$, and that rad $9 \Delta$ and rad $24 \Delta$ mutations had different effects on cell division. MATa cells were first arrested in G1 using the mating pheromone alpha factor, the pheromone was removed, and single cells incubated on plates for $20 \mathrm{~h}$ at $37^{\circ} \mathrm{C}$. After $20 \mathrm{~h}$ at $37^{\circ} \mathrm{C}$, $Y_{K U} 70^{+} R A D^{+}$and yku70s rad9s cells had formed much larger and more uniformly sized colonies $(>1000$

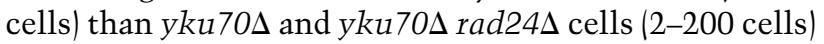
(Fig. 3a-d). This shows that deletion of RAD9, but not

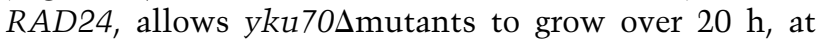
$37^{\circ} \mathrm{C}$, at rates indistinguishable from the rate of $Y K U 70^{+}$ cells. The behavior of yku70s checkpoints double mutants cultured at $37^{\circ} \mathrm{C}$ is in contrast to the behavior of cdc13-1 checkpoint $\Delta$ double mutants cultured at a similar temperature, as $c d c 13-1$ rad9s mutants formed smaller microcolonies at $36^{\circ} \mathrm{C}$ compared to the $c d c 13-1$ rad24s mutants (Lydall and Weinert 1997).

A model that might explain the different roles of $R A D 9$ and $R A D 24$ in responding to yku70s and cdc131 -induced damage is that $R A D 9$ is required for the primary checkpoint response in yku70s and cdc13-1 mutants, and that $R A D 24$ is required for arrest only when 
Maringele et al.

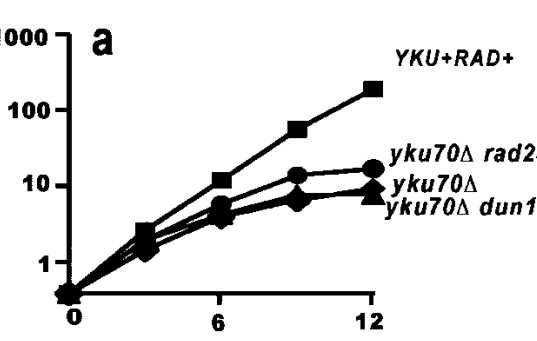

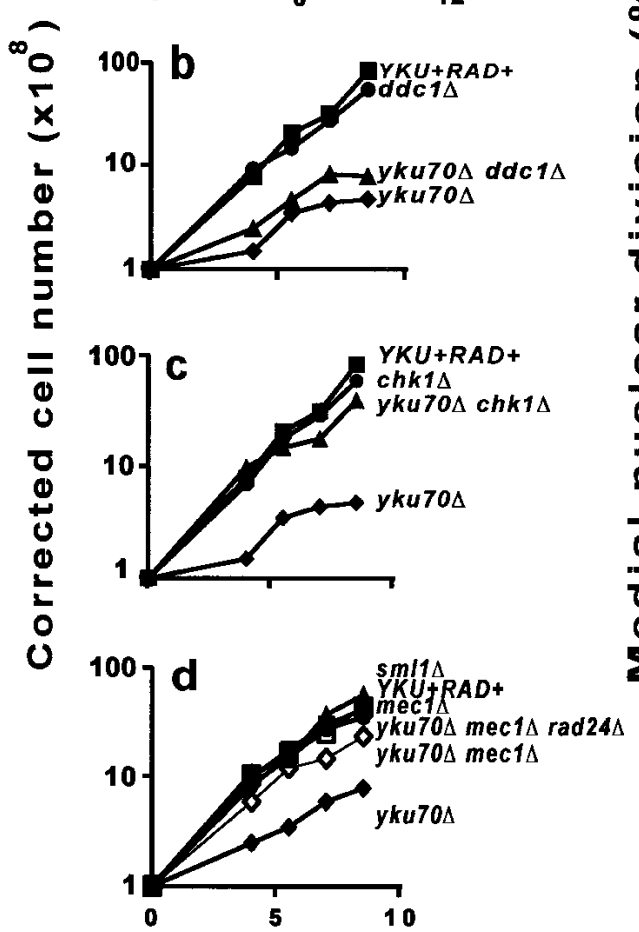

Time at $370 \mathrm{C}$ (hours)

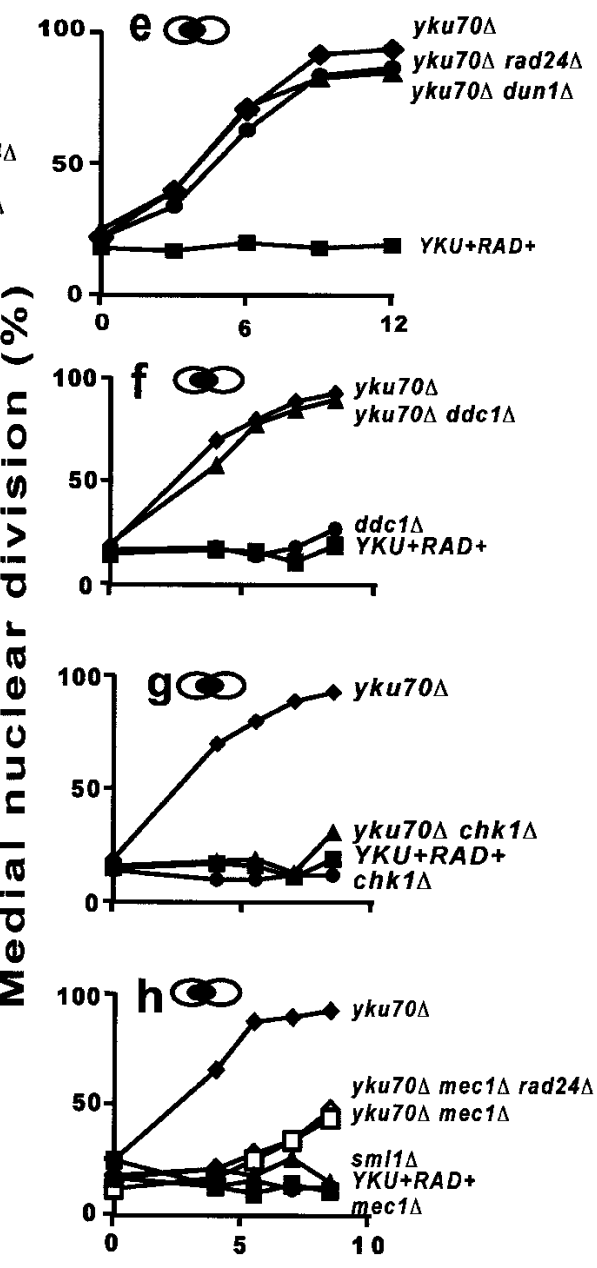

Time at $370 \mathrm{C}$ (hours)

Figure 2. RAD9, MEC1, and $C H K 1$ cause $\mathrm{G} 2 / \mathrm{M}$ arrest of $y k u 70 \Delta$ strains at $37^{\circ} \mathrm{C}$. A series of yeast strains dividing exponentially at $23^{\circ} \mathrm{C}$ were placed at $37^{\circ} \mathrm{C}$ and their growth and cell cycle distribution were monitored. At indicated time points, cells density was determined by hemocytometer $(a-d)$ and cell cycle distribution was determined by staining with DAPI $(e-h)$. The yeast stains used were $Y K U^{+} R A D^{+}$: DLY640 in $a, d, e, h$, and DLY641 in $b, c, e, f ; y k u 70 \Delta$ : DLY1412 in $a, e$, and DLY1366 in $b, c, d, f, g, h ; y k u 70 \Delta$ rad24s:

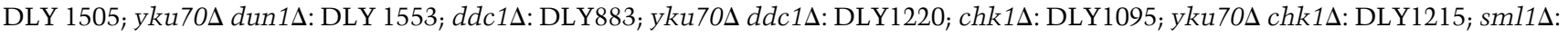

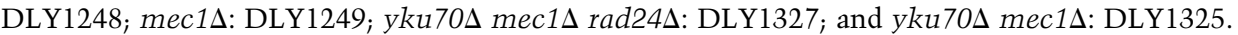

damage becomes more extensive. If true, this could explain why cdc13-1 mutants cultured at $36^{\circ} \mathrm{C}, 10^{\circ} \mathrm{C}$ higher than their maximum permissive temperature, depend on both RAD9 and RAD24 for cell cycle arrest (Lydall and Weinert 1995), whereas yku70د mutants, cultured at $37^{\circ} \mathrm{C}, 2^{\circ} \mathrm{C}$ higher than their maximum permissive temperature, depend on $R A D$ 9, but not on $R A D 24$. Wild-type yeast strains do not form colonies above $38^{\circ} \mathrm{C}$, and so it was not possible to test whether arrest of yku70s mutants at higher temperatures depends on $R A D 24$ as well as $R A D$ 9. However, it was possible to test whether arrest of $c d c 13-1$ mutants at marginally permissive temperatures depended more on $R A D 9$ than $R A D 24$. We used the microcolony assay to test whether $R A D 9$ was required for the primary checkpoint pathways in $c d c 13-1$ strains cultured at the moderately restrictive temperature of $28^{\circ} \mathrm{C}$. At this temperature, cdc13-1 cells formed colonies in the range of 2 to 20 cells, compared with $2-6$ cells at $36^{\circ} \mathrm{C}$ (Lydall and Weinert 1997); cdc13-1 rad9s cells formed medium-sized colonies (20-200 cells), whereas cdc13-1 rad24s and cdc13-1 cells formed large-sized colonies (1000-3000 cells) (Fig. 3e-h). Therefore, at both moderately $\left(28^{\circ} \mathrm{C}\right)$ and strongly $\left(36^{\circ} \mathrm{C}\right)$ restrictive temperatures, cdc13-1 rad9s mutants form smaller colonies than cdc13-1

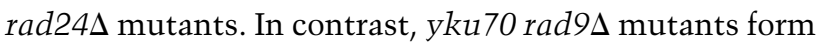

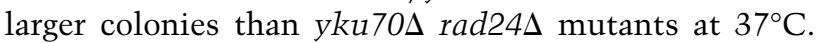
Therefore, we conclude that RAD9- and RAD24-dependent checkpoint pathways play different roles in re-

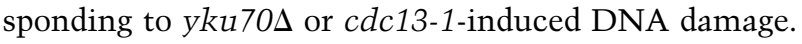

MAD2 contributes to the arrest of yku70s mutants and BUB2 to the arrest of cdc13-1 mutants

Despite their initial checkpoint-defective phenotype,

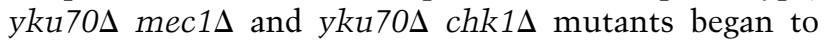




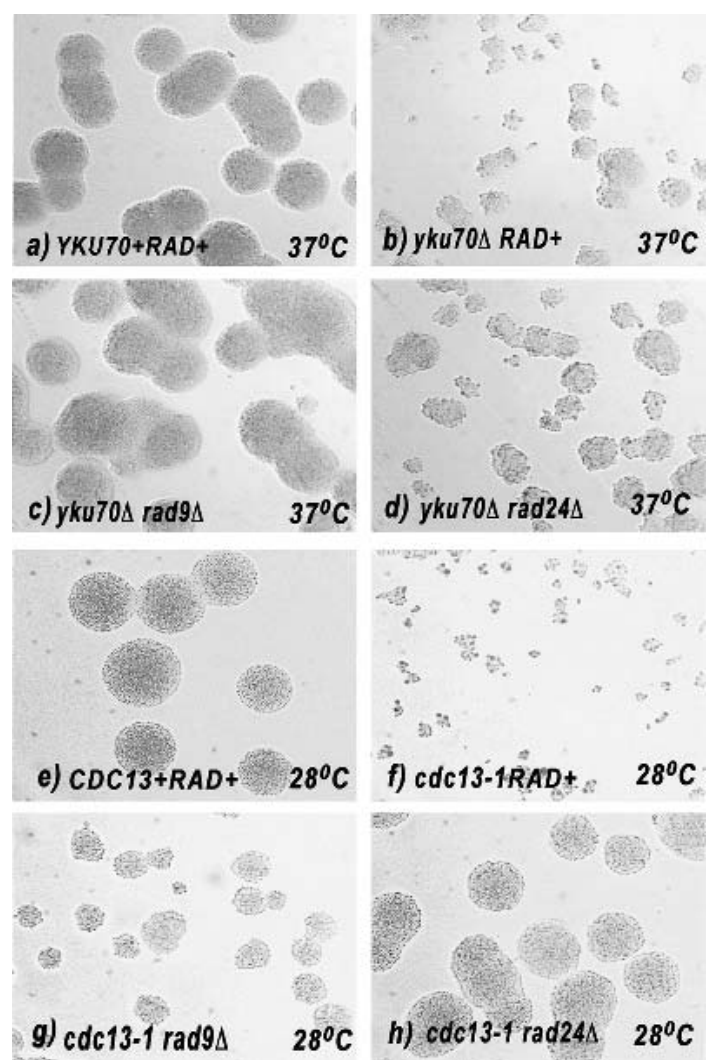

Figure 3. $R A D 9$ and $R A D 24$ have different effects on the growth of yku70s and cdc13-1 colonies. Single G1-arrested cells were spread on YEPD (ade) plates and photographed after 20-h growth. The yeast strains were $(a)$ DLY640, (b) DLY1412, (c) DLY1271, (d) DLY1364, (e) DLY640, (f) DLY1230, (g) DLY1255, and $(h)$ DLY1257.

slow cell division, and started to accumulate at medial nuclear division, after long periods $(8 \mathrm{~h})$ at $37^{\circ} \mathrm{C}$ (Fig. 2g,h). The MAD2-dependent spindle checkpoint arrests cells at a stage of cell division similar to the RAD9dependent DNA damage checkpoint, just prior to the metaphase/anaphase transition, when the APC (anaphase promoting complex) is activated. The MAD2-dependent checkpoint inhibits APC activation by inhibiting Cdc20p, an essential factor for APC activation (Hwang et al. 1998). To determine whether spindle checkpoint pathways might be responsible for the re-

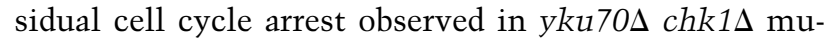
tants, we examined the effect of mad2 $\Delta$ and bub2 $\Delta$ mu-

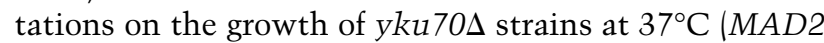
and $B U B 2$ belong to different arms of the spindle checkpoint pathways (Gardner and Burke 2000). Whereas a

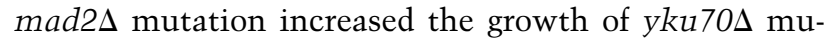
tants (Fig. 4a-c), a bub2s mutation had no effect on the

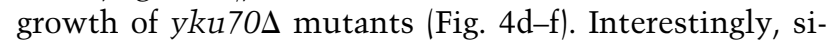
multaneous disruption of both RAD24 and MAD2 in-

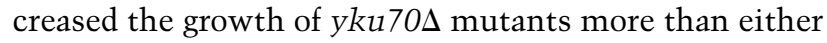
single mutation (Fig. 4b,c), suggesting that perhaps $R A D 24$ plays a small role in the arrest of yku70s mu- tants, a role that can be unmasked by deletion of MAD2.

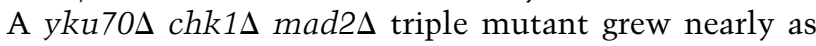
well as $Y K U 70^{+}$cells (Fig. 4c).

To determine whether the MAD2 spindle checkpoint also contributes to inhibiting the growth of $c d c 13-1 \mathrm{mu}-$ tants, we combined mad2s and bub2s mutations with $c d c 13-1$. Curiously, and once again, $c d c 13-1$ and

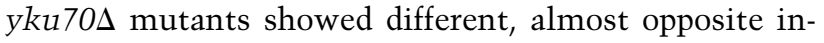
teractions with checkpoint pathways. A bub2s deletion had a moderate effect on the growth of $c d c 13-1$ mutants (Fig. 4j-1), whereas a mad2s deletion had less effect (Fig. $4 \mathrm{~g}-1)$. The effect of the bub2 $\Delta$ mutation was not as strong as a rad $9 \Delta$ DNA damage checkpoint mutation,

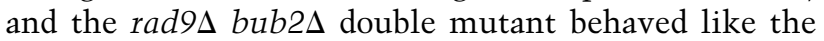
single rad9 $\Delta$ mutant (Fig. 4j-1). Similarly, the cdc13-1 rad9s mad2s triple mutants formed colonies with efficiency similar to that of the $c d c 13-1$ rad9s double mutants.

To confirm that MAD2 was responsible partially for

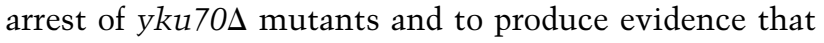
it contributed to the residual arrest observed in yku70s $\operatorname{chk} 1 \Delta$ mutants at $37^{\circ} \mathrm{C}$, we performed liquid culture experiments. Figure $4 \mathrm{~m}$ shows that the decrease in

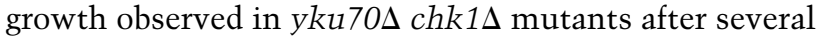
hours at $37^{\circ} \mathrm{C}$ (vs. YKU70 cells) could be overcome by a

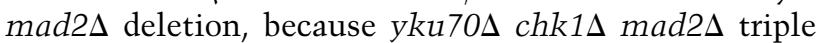
mutants grew almost as well as the $Y K U 70^{+}$strain. Fig-

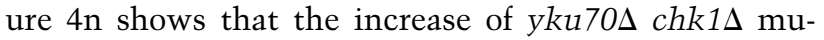
ants at medial nuclear division, during 9-18 $\mathrm{h}$ of incu-

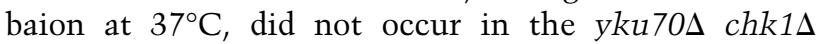

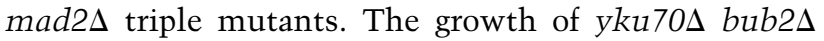

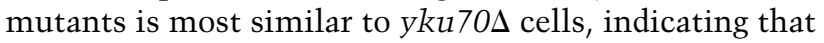
BUB2 does not play a role in the arrest of yku70s mutants at $37^{\circ} \mathrm{C}$. Consistent with the hypothesis that yku70 damage induces a MAD2-dependent arrest,

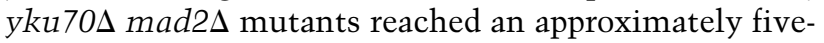
fold higher cell density than yku70s cells over an 18-h period (Fig. $4 \mathrm{~m}$ ). In addition, a maximum of $75 \%$ of yku70s mad2s mutants arrested at medial nuclear division, whereas about $95 \%$ of yku70s cells arrested (Fig. 4n).

We have shown that arrest of $y k u 70 \Delta$ mutants at $37^{\circ} \mathrm{C}$ is due to CHK1- and MAD2-dependent pathways; Figure $4 \mathrm{n}$ allows us to estimate their respective contributions. A CHK1-dependent pathway is responsible for $75 \%$ of arrest (determined from the percentage of yku70s mad2 $\Delta$ mutants arrested at the time point of maximum arrest, $12 \mathrm{~h}$ ), whereas a $M A D 2$-dependent pathway is responsible for $20 \%$ of the arrest (determined from the percentage of yku70د mutants arrested minus the per-

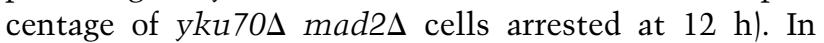

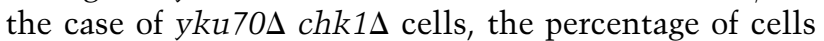
arrested by MAD2 only noticeably increased at later time points (over $15 \mathrm{~h}$ ), consistent with the idea that at early times arrested cells were diluted by the large mass of dividing cells. Thus, the effects of the CHK1dependent DNA damage and MAD2-dependent spindle checkpoint pathways are additive and together they contribute to all $(95 \%)$ of the arrest observed in yku $70 \Delta \mathrm{mu}-$ tants. 

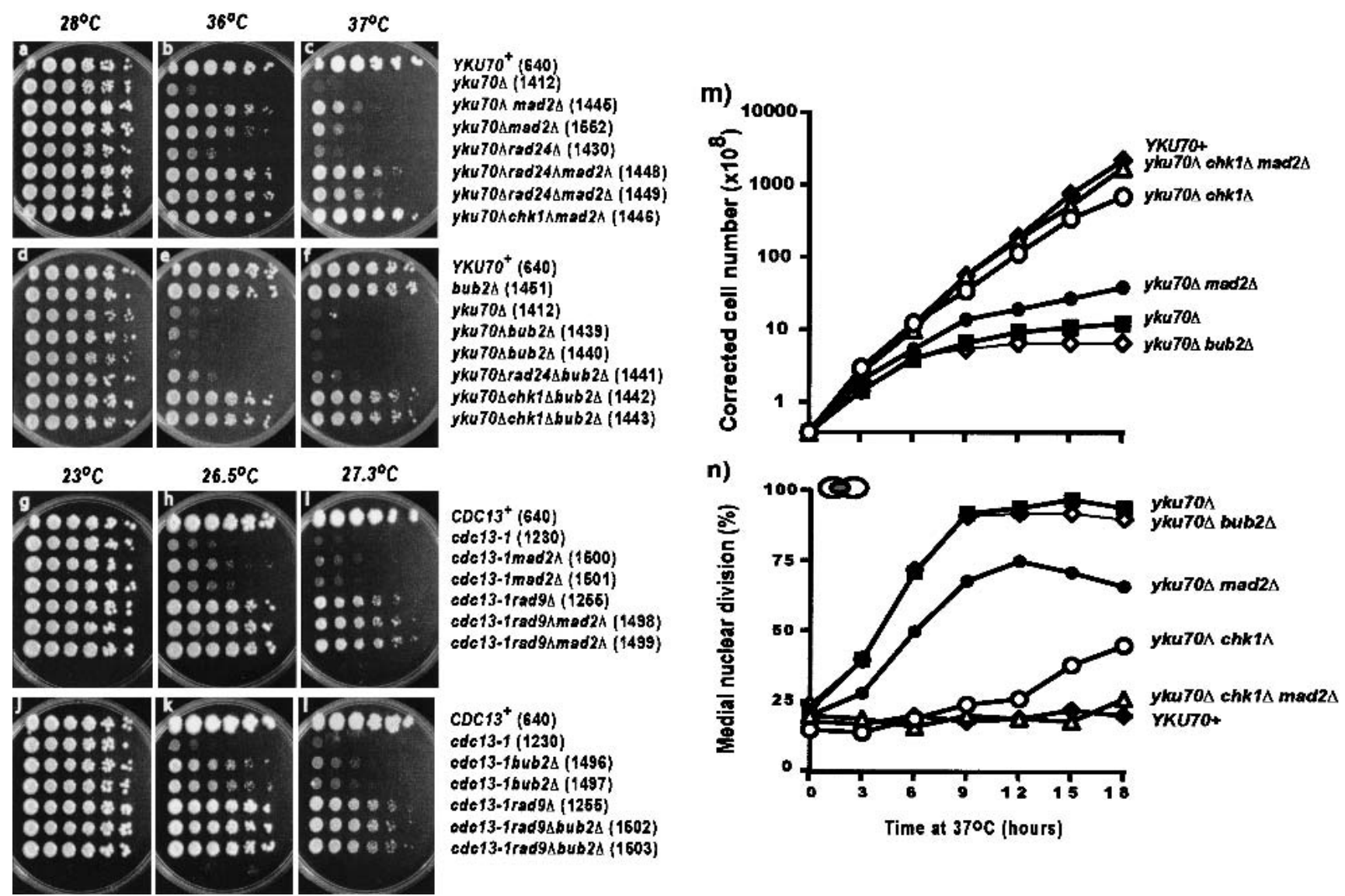

Figure 4. MAD2 inhibits the growth of yku70s mutants, while BUB2 inhibits growth of $c d c 13-1$ mutants. (a-1) Small aliquots of fivefold dilution series of several yeast strains were transferred to plates and incubated for $2 \mathrm{~d}(a-f)$ or $3 \mathrm{~d}(g-l)$ before being photographed. The relevant genotypes of the strains are indicated on the left and the strain numbers shown in parentheses. $(m, n) \mathrm{A}$ series of yeast strains dividing exponentially at $23^{\circ} \mathrm{C}$ was placed at $37^{\circ} \mathrm{C}$ and their growth and cell cycle distribution were monitored. At indicated time points, cell density was determined by hemocytometer and cell cycle distribution was determined by staining with

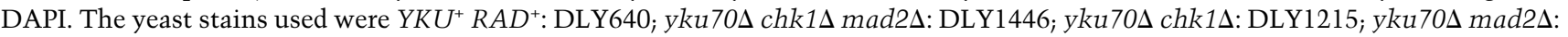

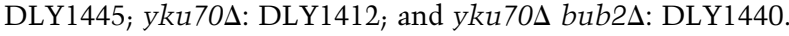

yku70 $\Delta$ mutants accumulate ssDNA in subtelomeric $Y^{\prime}$ sequences at $37^{\circ} \mathrm{C}$

There is much evidence that single-stranded DNA is an important stimulus for DNA damage checkpoint pathways. For example, cdc13-1 mutants accumulate ssDNA up to $20 \mathrm{~kb}$ from their telomeres, when cultured at restrictive temperatures (Garvik et al. 1995). If ssDNA is an important component of the signal that activates checkpoint pathways in yku $70 \Delta$ mutants at $37^{\circ} \mathrm{C}$, then increased levels should be observed at restrictive temperatures. It was known that yku70s and yku80s mutants contain more ssDNA in their repetitive TG telomeric sequences than do $\mathrm{KKU}^{+}$cells (Gravel et al. 1998; Polotnianka et al. 1998; Teo and Jackson 2001). How-

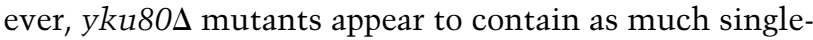
stranded TG DNA at their permissive temperatures of $23^{\circ} \mathrm{C}$ and $30^{\circ} \mathrm{C}$ as at their restrictive temperature of $37^{\circ} \mathrm{C}$ (Gravel et al. 1998; Teo and Jackson 2001), suggesting that ssDNA at telomeric sequences is not necessarily an important stimulus for cell cycle arrest (Teo and Jackson
2001). We reasoned that the ssDNA in yku70s mutants might extend beyond the telomeres, as it does in $c d c 13-1$ mutants, and that there may be a better correlation between the appearance of ssDNA in subtelomeric repeats and cell cycle arrest.

Quantitative amplification of ssDNA (QAOS) (Booth et al. 2001) was used to examine the appearance of ssDNA in telomere proximal sequences of yku70s mutants at $37^{\circ} \mathrm{C}$ (Fig. 5). This quantitative PCR-based method can be used to measure ssDNA levels in the range $0.2 \%$ to $100 \%$ at single-copy loci in the genome. We found that yku70s mutants cultured at the restrictive temperature of $37^{\circ} \mathrm{C}$ generated increasing amounts of ssDNA at subtelomeric loci. We measured ssDNA at a locus situated $600 \mathrm{bp}$ from the telomeric end of the $\mathrm{Y}^{\prime}$ subtelomeric repeat. In telomeres that contain $\mathrm{Y}^{\prime}$ repeats, this locus is about 900-1000 bp from the very end of the chromosome (Fig. 5a). At these positions, the amount of ssDNA in yku70s mutants increased from $1.6 \%$ at the beginning of the experiment to values between $5 \%$ and $8 \%$, after $6-10 \mathrm{~h}$ of incubation at $37^{\circ} \mathrm{C}$ 
a)

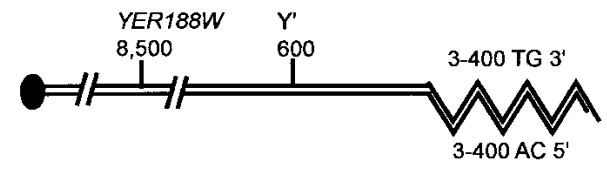

b)

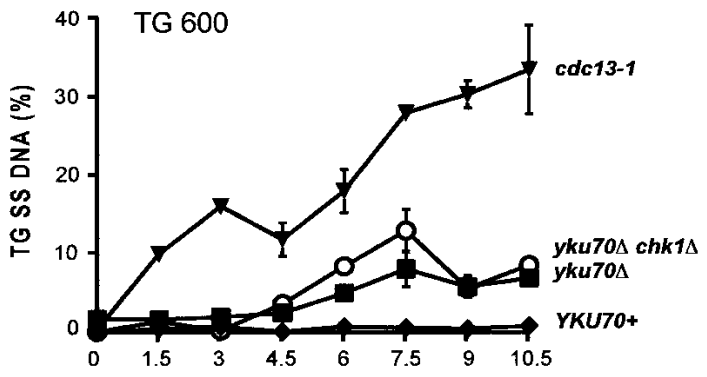

c)

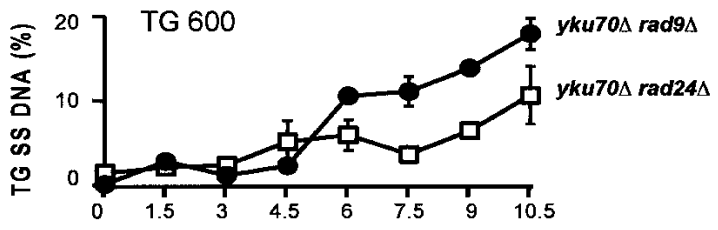

d)

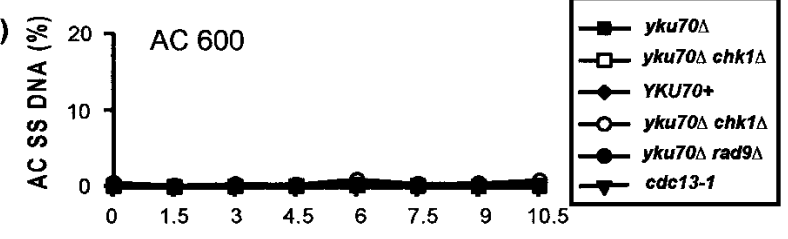

e)

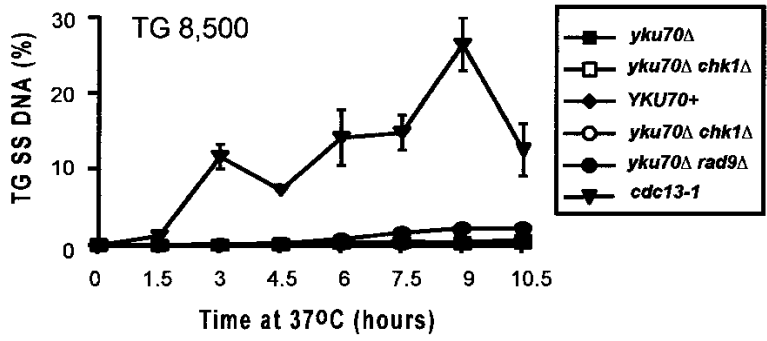

Figure 5. yku70s mutants accumulate ssDNA in subtelomeric sequences. A series of yeast strains was cultured at $37^{\circ} \mathrm{C}$, and the amount of ssDNA at their telomeres was measured by quantitative amplification of ssDNA (QAOS). The yeast stains used were cdc13-1: DLY1230; yku70s chk1s: DLY1215;

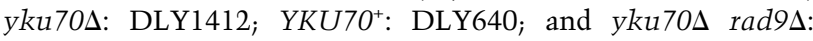

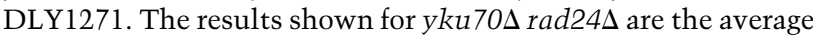
amount of ssDNA observed in two independent strains DLY1364 and DLY1430. The error bars indicate the standard error of the mean derived from three independent measurements of the amount of ssDNA in a sample, except for the

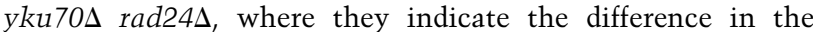
amount of ssDNA in the two strains. (a) A schematic model of the telomere of chromosome $\mathrm{V}$ in budding yeast. $(b, c)$ Detection of ssDNA on the TG strand 600 bases from the telomeric end of the $\mathrm{Y}^{\prime}$ sequence. (d) Detection of ssDNA on the AC strand, 600 bases from the telomeric end of the $\mathrm{Y}^{\prime}$ sequence. (e) Detection of ssDNA on the TG strand at YER188W, 8500 bases from the right end of chromosome $\mathrm{V}$.

(Fig. 5b). The increase in ssDNA is less rapid and less extensive than that observed in $c d c 13-1$ mutants during the same experiment, but the amount of ssDNA is significantly higher than that observed in control $Y K U 70^{+}$ cells (Fig. 5b). No ssDNA was detected on the AC strand in any strains (Fig. 5d). Therefore, the ssDNA observed in

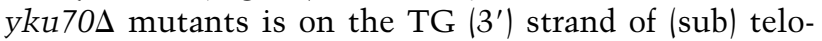
meres and is presumably caused by loss of the AC $\left(5^{\prime}\right)$ strand, as in $c d c 13-1$ mutants. The increase in the levels of ssDNA in $\mathrm{Y}^{\prime}$ sequences with time at $37^{\circ} \mathrm{C}$ is consistent with the hypothesis that the subtelomeric ssDNA in yku70s mutants contributes to activation of the RAD9, CHK1, and MEC1-dependent checkpoint pathway. There is a clear correlation between the accumulation of ssDNA at the $\mathrm{Y}^{\prime} 600$ locus, after a 6-h incubation at $37^{\circ} \mathrm{C}$ (Fig. 5b) and the accumulation of cells at medial nuclear division in checkpoint-proficient yku70s cells (Figs. 2 and 4n).

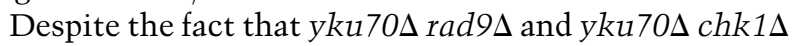

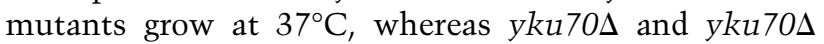
rad24 $\Delta$ did not, all of these mutants accumulated comparable amounts of ssDNA, arguing that their different growth phenotypes are not due to differences in the amount of DNA damage among these strains. Interestingly, the strains that did not grow at $37^{\circ} \mathrm{C}$, the yku70s and yku70 $\Delta$ rad2 $4 \Delta$ strains, had marginally less ssDNA

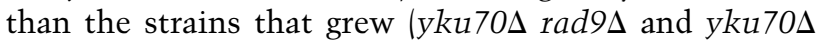
$\operatorname{chk} 1 \Delta$; Fig. $5 \mathrm{~b}, \mathrm{c})$. This observation, together with the cell cycle distribution results (Fig. 2) argues that checkpoint genes differ in their ability to induce arrest, rather than in their ability to affect the production of ssDNA in

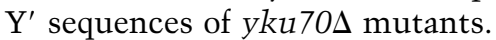

The effect of checkpoint genes on the production of ssDNA in $c d c 13-1$ mutants is easily detected at a locus $12 \mathrm{kbp}$ from the telomere, $c d c 13-1 \mathrm{rad} 9 \Delta$ mutants generate ssDNA more rapidly than $c d c 13-1$ cells, which in turn generate ssDNA more rapidly than $c d c 13-1$ rad24s cells (Lydall and Weinert 1995). To investigate whether yku70s mutants generate ssDNA beyond the $\mathrm{Y}^{\prime}$ sequences, we examined ssDNA production at the YER188W locus, 8,500 bp from the telomere. This is the first unique gene close to the right telomere of chromosome V. Figure 5e shows that yku70 mutants generate considerably less ssDNA at this locus compared to cdc13-1 mutants, and compared to the amount of ssDNA they generate at their $\mathrm{Y}^{\prime}$ sequences. Interestingly, yku70 $\mathrm{rad} 9 \Delta$ mutants generated some ssDNA at YER188W, which suggests that $R A D 9$ may inhibit ssDNA production in yku70s mutants, as it does in cdc13-1 mutants (Lydall and Weinert 1995).

In summary, we find that yku70s mutants contain significantly more subtelomeric ssDNA at restrictive temperatures than at permissive temperatures. This suggests that the subtelomeric ssDNA is an important stimulus for activation of checkpoint control pathways in yku70s mutants.

EXO1 is required for ssDNA generation and arrest of yku70s mutants

If ssDNA contributes to the signal that arrests cell divi-

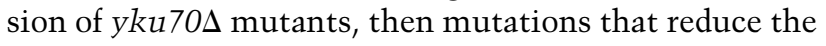


amount of ssDNA should alleviate arrest. To test this hypothesis, we examined the effect of an exo1s muta-

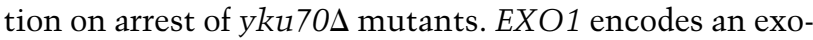
nuclease that is normally recruited to DNA by the mismatch repair machinery (Tishkoff et al. 1997) and is involved in the resection of meiotic DSBs (Tsubouchi and Ogawa 2000), but does not appear to affect telomere length (Tsubouchi and Ogawa 2000). The resection of meiotic DSBs by $5^{\prime}$ to $3^{\prime}$ exonucleases, to generate $3^{\prime}$ ssDNA tails, is in many ways similar to the processes that occur at damaged telomeres, which also produce $3^{\prime}$ ssDNA tails. Figure 6a shows that an exo1s mutation strongly increases the ability of yku70s mutants to form colonies at $36^{\circ} \mathrm{C}$ and $37^{\circ} \mathrm{C}$. The effect is as strong as that seen with a $\operatorname{chk} 1 \Delta$ mutation (cf. Figs. 6 and 1). To determine whether the strong growth is due to alleviation of checkpoint control, we examined the cell cycle distribution of yku70s exo1s double mutants in liquid cultures and found that yku70s exo1s mutants do not accumulate in medial nuclear division (Fig. 6b).

To determine whether EXO1 was required for the production of ssDNA in yku70 $\Delta$ mutants, we used QAOS to measure ssDNA production in $\mathrm{Y}^{\prime}$ sequences during growth at $37^{\circ} \mathrm{C}$ (Fig. 6c). It is clear that yku70s exo1s mutants contain extremely low levels of ssDNA at subtelomeric sequences at both $20^{\circ} \mathrm{C}$ and $37^{\circ} \mathrm{C}$. The levels are indistinguishable from the levels in $Y K U 70^{+}$cells. No ssDNA was detected on the AC strand at telomeres (Fig. 6d). Thus, it appears that EXO1 plays an important role in the accumulation of ssDNA in yku70s mutants and that in the absence of this EXO1-dependent ssDNA, yku70s mutants do not arrest cell division at $37^{\circ} \mathrm{C}$.

\section{EXO1 contributes to ssDNA production} in cdc13-1 mutants

Since EXO1 is required to generate ssDNA at the telomeres of yku70D mutants, we asked whether EXO1 is also required to generate ssDNA and induce cell cycle arrest in $c d c 13-1$ mutants. Figure 7 a shows that $c d c 13-1$ exo1s double mutants arrest at medial nuclear division, as do $c d c 13-1$ mutants, when cultured at $37^{\circ} \mathrm{C}$, but with slower kinetics. Therefore, EXO1 contributes to, but is not completely required for, the arrest of $c d c 13-1 \mathrm{mu}-$ tants grown at $37^{\circ} \mathrm{C}$. When we examined the effect of EXO1 on the appearance of ssDNA at the $\mathrm{Y}^{\prime} 600$ locus in cdc13-1 mutants, we found that ssDNA did appear in cdc13-1 exo1s mutants, reaching a level of about $6 \%$ after $1.5 \mathrm{~h}$ at $37^{\circ} \mathrm{C}$ and largely staying at this level for the rest of the experiment. This level of ssDNA was considerably less than the $30 \%$ level of ssDNA observed in cdc13-1 EXO1 strains (Fig. 7b). We conclude that EXO1 contributes to ssDNA generation in cdc13-1 mutants, but that another exonuclease (ExoX) must also contribute to the production of ssDNA in cdc13-1 mutants.

\section{MRE11 protects telomeres in yku70s mutants}

EXO1 functions redundantly with MRE11 to process DSBs to create $3^{\prime}$ ssDNA tails (Tsubouchi and Ogawa

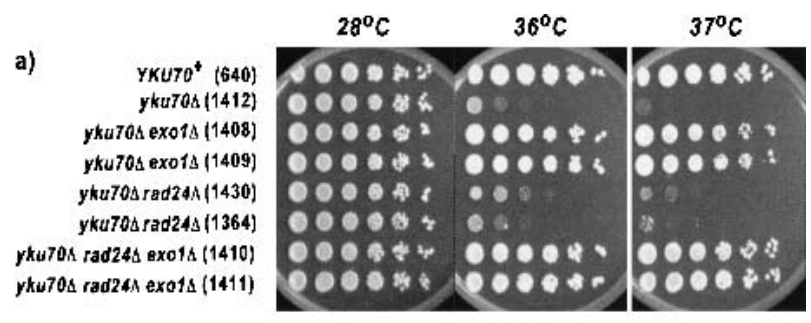

b)

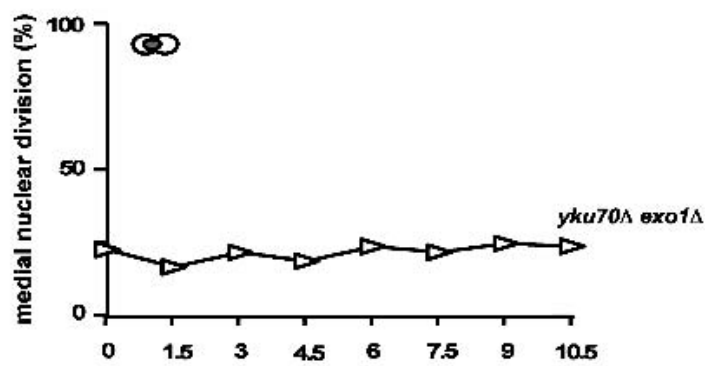

c)

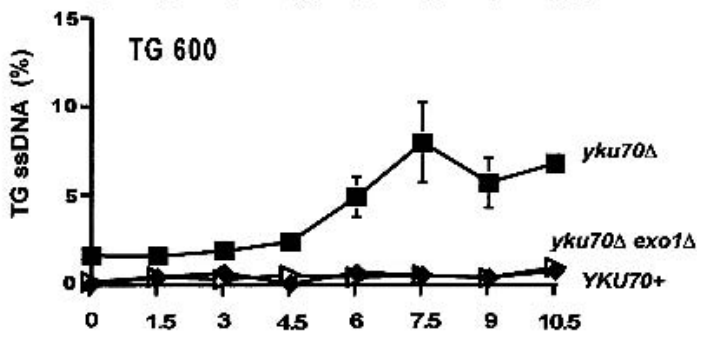

d)

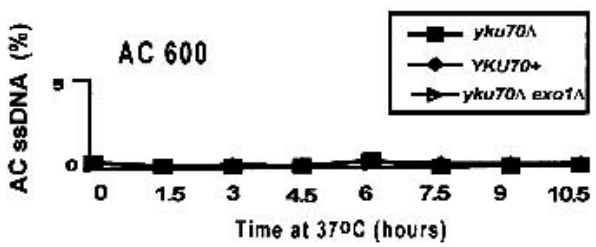

Figure 6. EXO1 is required for arrest and ssDNA generation in

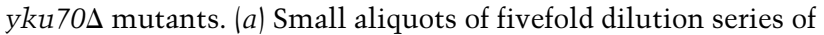
several yeast strains were transferred to plates and incubated at $28^{\circ} \mathrm{C}, 36^{\circ} \mathrm{C}$, or $37^{\circ} \mathrm{C}$ for $2 \mathrm{~d}$ before being photographed. The relevant genotypes of the strains are indicated on the left, and the strain numbers shown in parentheses. (b) A yku70s exo1s (DLY1408) yeast strain dividing exponentially at $20^{\circ} \mathrm{C}$ was placed at $37^{\circ} \mathrm{C}$, and its cell cycle distribution was monitored by staining with DAPI (see Figs. 2 and $4 \mathrm{n}$ for the behavior of control strains). (c) Detection of ssDNA on the TG strand 600 bases from the telomeric end of the $\mathrm{Y}^{\prime}$ sequence. The yeast strains were yku70s: DLY1412; yku70s exo1s: DLY1408; and

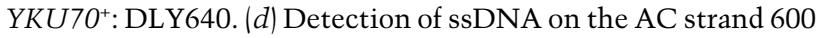
bases from the telomeric end of the $\mathrm{Y}^{\prime}$ sequence. The yeast strains are as in $c$.

2000) and in other aspects of DNA damage metabolism (Moreau et al. 2001; Lewis et al. 2002). Therefore, it was possible that MRE11 also played a role in generating ssDNA in yku70s mutants. It was shown previously

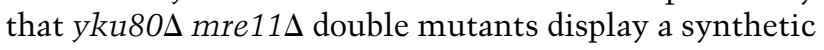
poor growth phenotype (Nugent et al. 1998), which is opposite to the phenotype observed in yku70s exo1s strains (Fig. 6a), suggesting that MRE11 does not have EXO1-type properties when combined with a yku70s defect. To test this directly, we combined yku70s, 

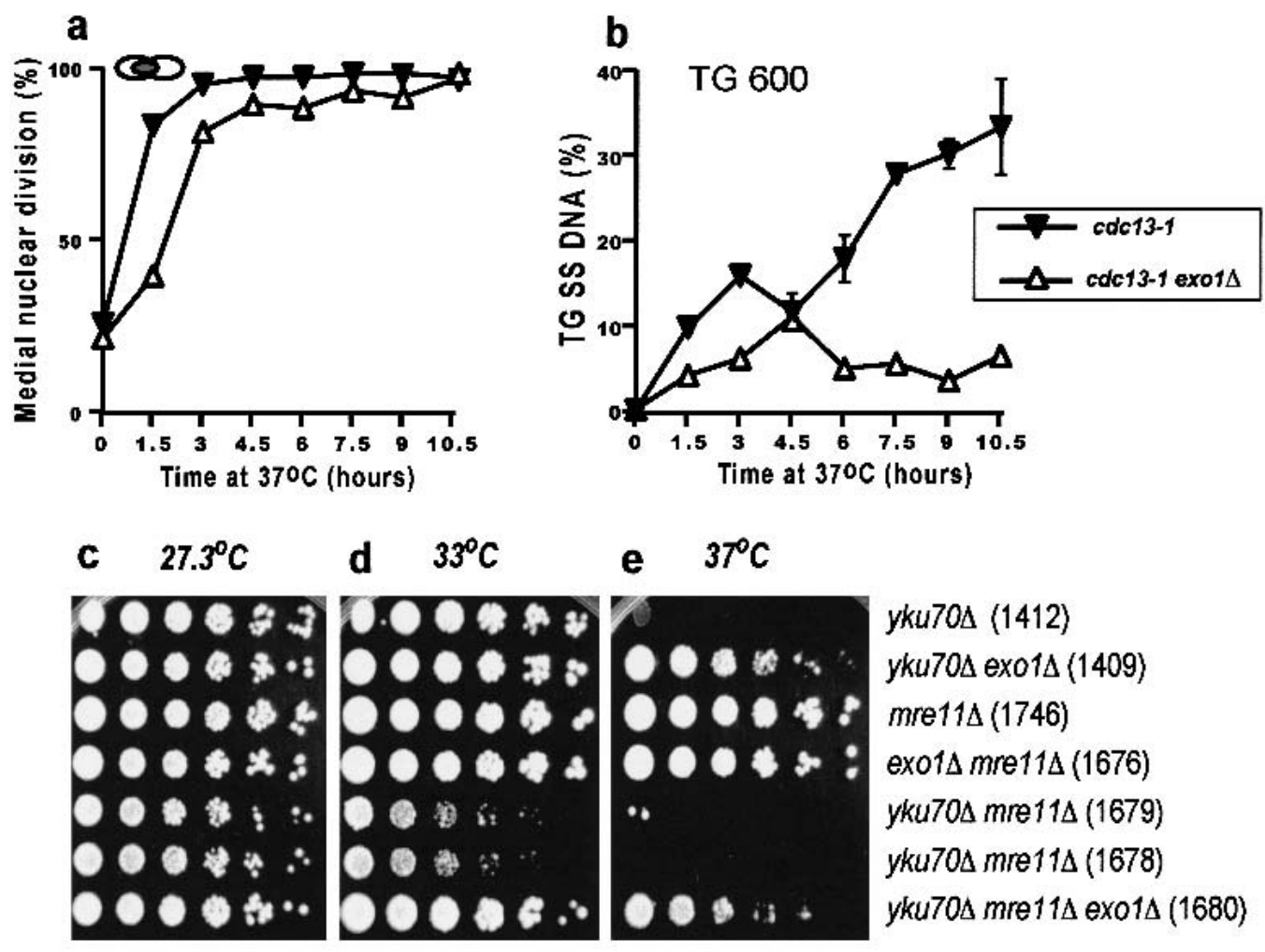

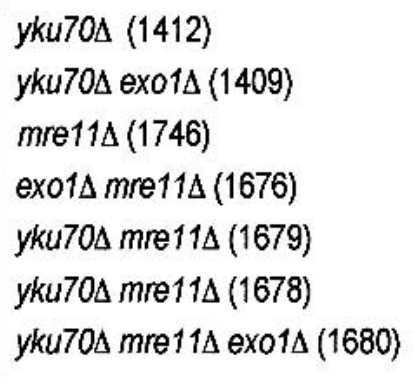
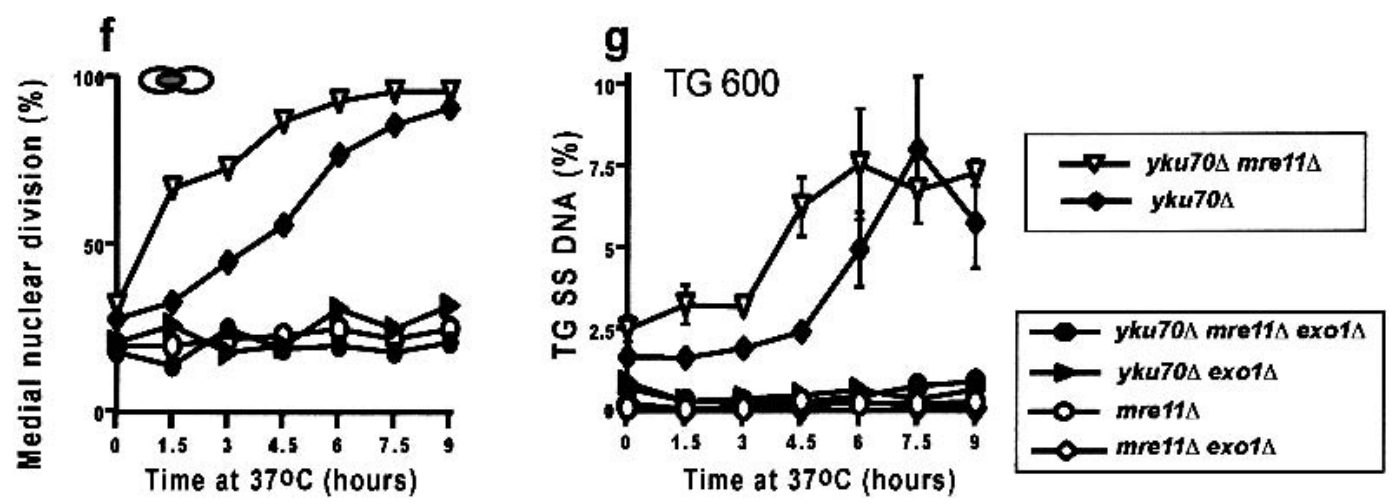

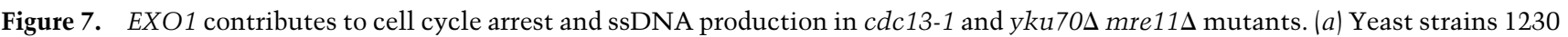
(cdc13-1) and 1296 (cdc13-1 exo1s) dividing exponentially at $20^{\circ} \mathrm{C}$ were placed at $37^{\circ} \mathrm{C}$, and the fraction of cells in medial nuclear division was monitored by staining with DAPI. (b) Detection of ssDNA on the TG strand 600 bases from the telomeric end of the $\mathrm{Y}^{\prime}$ sequence. The yeast strains were as in $a .(c, d, e)$ Small aliquots of fivefold dilution series of several yeast strains were transferred to plates and incubated for $2 \mathrm{~d}$ before being photographed. The relevant genotypes of the strains are indicated on the right, and the strain numbers are shown in parentheses. $(f)$ Yeast strains dividing exponentially at $20^{\circ} \mathrm{C}$ were placed at $37^{\circ} \mathrm{C}$, and their cell cycle distribution

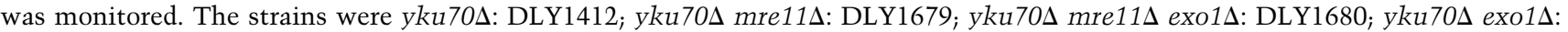

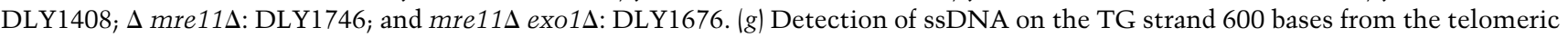
end of the $\mathrm{Y}^{\prime}$ sequence. The yeast strains were as in $f$.

exo1s, and mre11s mutations and examined their effects on growth, cell cycle arrest, and ssDNA production. Figure 7c-e shows that yku70s mre $11 \Delta$ double mutants are more temperature-sensitive than yku70s mutants. Interestingly, this temperature-sensitive growth phenotype is dependent on EXO1 (Fig. 7e). Liquid culture experiments demonstrated that yku70s mre11s double mutants arrested at medial nuclear division more rapidly than yku70s single mutants, arguing that MRE11 func- tions to maintain telomere structure in yku70s mutants, rather than to degrade telomere structure, as EXO1 does. The mre11s yku70s exo1s triple mutant did not arrest cell division at $37^{\circ} \mathrm{C}$ over a 9-h time course, suggesting that EXO1-dependent ssDNA is required for the cell cycle arrest of yku70s mre11s mutants cultured at $37^{\circ} \mathrm{C}$.

Accumulation of telomeric ssDNA in yku70s mre11s mutants provides an explanation for their rapid arrest at 
medial nuclear division at $37^{\circ} \mathrm{C}$. Even at $20^{\circ} \mathrm{C}$ (at the beginning of the experiment), yku70s mre11s double mutants contain more ssDNA than yku70s mutants in their $Y^{\prime}$ sequences (Fig. 7g). Furthermore, the amount of ssDNA increases more rapidly in yku $70 \Delta$ mre $11 \Delta$ double mutants than in yku70s mutants, which is consistent with the more rapid arrest observed in these strains. Finally, all of the ssDNA in yku70s mre11s double mutants appears to be dependent on EXO1.

\section{Discussion}

In this study, we examined the interactions of checkpoint pathways with the damaged telomeres that are pre-

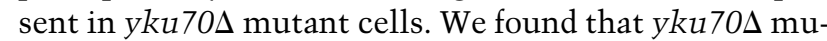
tants, like $c d c 13-1$ mutants cultured at $37^{\circ} \mathrm{C}$, contain increased levels of ssDNA in subtelomeric sequences. However, the amount of ssDNA observed in yku70s mutants is considerably less than in cdc13-1 mutants. We demonstrated that EXO1 but not MRE11 is required for the production of this ssDNA and for cell cycle arrest. The correlation between the amount of ssDNA and cell cycle arrest in yku70s mutant cells is in many ways analogous to the situation observed with DSBs, when strains with more ssDNA arrest cell division for longer (Lee et al. 1998).

Interestingly, the damage induced in yku70s mutants activates a $R A D 9, C H K 1$, and MEC1-dependent checkpoint pathway, but is independent of $R A D 17, R A D 24$, $M E C 3, D D C 1$, and DUN1, whereas arrest of $c d c 13-1$ mutants is dependent on all eight genes. yku70s-induced damage is the first type of DNA damage demonstrated to have these properties. A complementary pathway appears to exist in meiosis, because prophase arrest of $d m c 1 \Delta$ mutants, which cannot complete meiotic recombination, depends on RAD24 but is independent of RAD9 and CHK1 (Bishop et al. 1992; Lydall et al. 1996; Roeder and Bailis 2000).

We propose a model to explain the functions of checkpoint proteins in responding to (sub) telomere defects in cdc13-1 and yku70s mutants (Fig. 8). According to this model, in $c d c 13-1$ mutants, unprotected telomeres are perceived as DSBs with a short 3' overhang. The Rad24p/ Rfc2-5p clamp loader complex (Green et al. 2000) recognizes this structure and loads the Ddc1p, Mec3p, Rad17p sliding clamp (Venclovas and Thelen 2000). The sliding clamp tethers an unknown protein, " $\mathrm{P}$ " (e.g., a helicase), which processes the telomeric termini to generate the "1st processed DNA damage". The " 1 st processed DNA damage" is the substrate that activates a Meclp/Rad53p/ Dunlp-dependent checkpoint pathway. Rad9p might also participate in Rad53p activation (Gilbert et al. 2001). Rad53p and Dun $1 \mathrm{p}$ are known to be responsible for $50 \%$ of the arrest observed in cdc13-1 mutants (Gardner et al. 1999). We suggest that protein "P" is then replaced by Exolp and by another 5' to 3' exonuclease ExoXp, which have affinity for the "1st processed DNA damage." The ssDNA generated by Exolp and ExoXp activates a Rad9p/Meclp/Chk1p- and Pds1p-dependent pathway. Chk1p/Pds1p are required for $50 \%$ of the arrest observed in cdc13-1 mutants. Thus, together Rad53p/Dun1p and Chk1p/Pds1p pathways are responsible for $100 \%$ arrest of $c d c 13-1$ cells (Gardner et al. 1999; Sanchez et al. 1999). In yku70s mutants, unprotected telomeres are also perceived as DSBs with a short $3^{\prime}$ overhang. But in cells lacking Yku70p, Exolp can be recruited independently of $\operatorname{Rad} 24 p$ and the Rad17p, Mec3p, Ddclp sliding clamp. Exolp generates ssDNA that activates the Rad9p/ Mec1p/Chk1p- and Pds1p-dependent checkpoint pathway. In yku70 mutants, this checkpoint pathway is responsible for the arrest of $75 \%$ of cells, and together with a $M A D 2$-dependent pathway, results in arrest of $95 \%$ of cells (see Fig. 4n).

Rad24p, the sliding clamp, and protein P might play a minor role in responding to yku70 4 -induced DNA damage, but the " $11^{\text {st }}$ processed DNA damage" does not form to a sufficient extent to activate Rad53p and Dun1p. Teo and Jackson (2001) showed that Rad53p kinase is activated at $37^{\circ} \mathrm{C}$ in yku80s mutants, but at very low levels. Pellicioli et al. (1999) showed that cells released from hydroxyurea arrest contain residual Rad53 kinase activity, even when the cell cycle has restarted. Therefore, a threshold of Rad53p kinase activity may be necessary to cause cell cycle arrest, and this threshold may not be reached in yku70s mutants.

This model raises many questions, most importantly: Why do $D D C 1, M E C 3, R A D 17, R A D 24$, and DUN1 play insignificant roles in the arrest of yku70 mutants? We suggest the following, not mutually exclusive, hypotheses: (1) Rad24p cannot bind to telomeres in yku70s mutants; (2) The " 1 st processed DNA damage" is not generated in yku70s mutants; (3) "ExoXp" is not recruited to telomeres in yku70s mutants; and (4) Exolp competes with "ExoXp" for substrates and is preferentially recruited to telomeres in yku70s mutants.

Our experiments reveal for the first time the role of the spindle checkpoint in arresting yku70s mutants at $37^{\circ} \mathrm{C}$. MAD2 contributes to the arrest of yku70 $\mathrm{mu}-$ tants, whereas BUB2 has no significant effect. Other studies have also shown interactions between mitotic spindle checkpoint pathways and cells that contain DNA damage. For example, all of the thymic lymphomas that developed in Brca2 knockout mice, defective in a protein thought to be involved in DNA repair /Venkitaraman 2002), had generated mutations in spindle checkpoint pathways Bub1 and Mad3 (Lee et al. 1999). Drosophila double parked mutants, defective in a homo$\log$ of CDT1, a gene whose product is required for DNA replication in fission yeast and Xenopus, depend on both DNA damage and spindle checkpoint genes to block cell division (Garner et al. 2001). bub2 mutations, but not mad2 mutations, allow cdc13-1 mutants to rebud and reduplicate their DNA, without completing anaphase (Wang et al. 2000). Finally, recent experiments demonstrated that Rad53p is required to modify Bfalp, the partner of Bub2p in response to $c d c 13-1$-induced DNA damage (Hu et al. 2001).

In our present experiments, the fraction or cells arrested by the $M A D 2$-spindle checkpoint pathway was about fourfold lower than that arrested by the DNA dam- 
a)

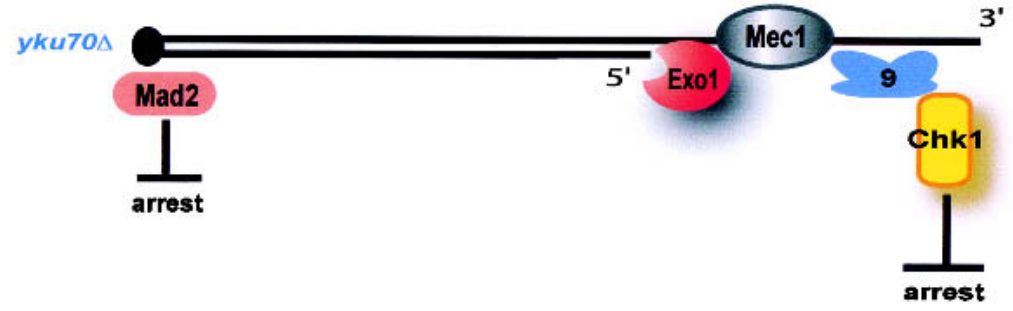

b)

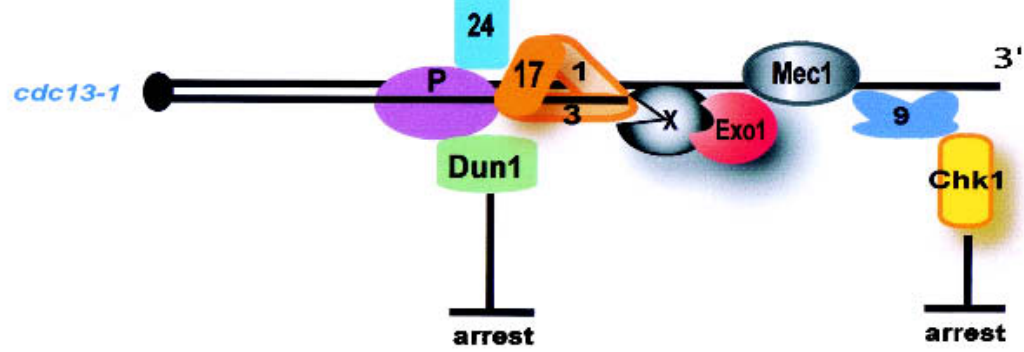

c)

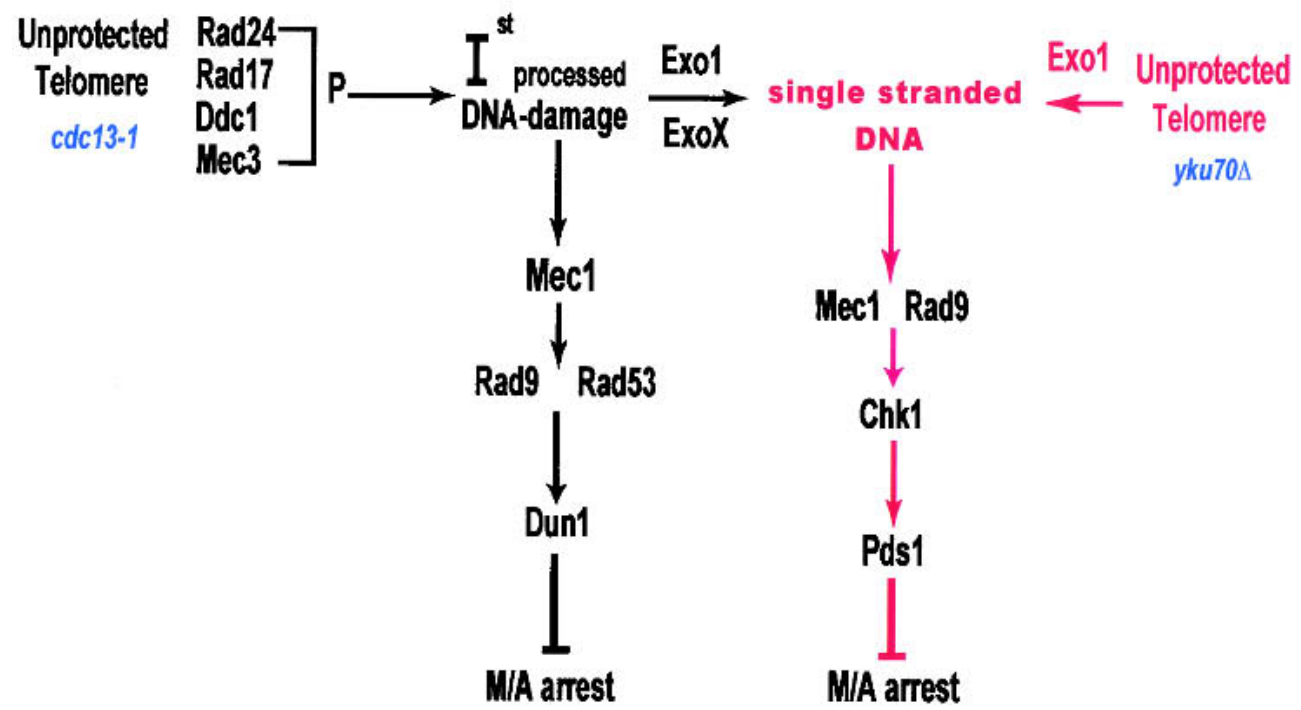

Figure 8. A model for the roles of checkpoint proteins in responding to $c d c 13-1$ and $y k u 70 \Delta$-induced DNA damage. (a) A representation of the proteins that are responsible for the arrest of yku70s mutants. (b) A representation of proteins that are responsible for the arrest of $c d c 13-1$ mutants. (c) A schematic model of the DNA damage checkpoint pathways responsible for metaphase/anaphase arrest of $c d c 13-1$ and yku70s mutants.

age checkpoint (Fig. $4 \mathrm{n})$. In a culture of $y k u 70 \Delta \operatorname{chk} 1 \Delta$ cells, missing DNA damage checkpoint control, the fraction of cells arrested at the spindle checkpoint increased to about $20 \%$ after $18 \mathrm{~h}$. This shows that the spindle checkpoint can substitute for the DNA damage checkpoint and stop cells with damaged telomeres from divid-

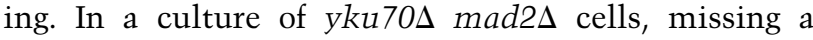
spindle checkpoint pathway, the fraction of cells arrested at the DNA damage checkpoint reached a maximum of $75 \%$ (after $12 \mathrm{~h}$; Fig. $4 \mathrm{n}$ ). Why did the remaining $25 \%$ of cells fail to arrest? Presumably these cells were not arrested by the DNA damage checkpoint because they did not contain DNA damage. Instead, they appear to have generated another defect that triggers arrest by the MAD2-dependent spindle checkpoint pathway. It is interesting that during the time course of our experiment the fraction of dividing cells did not significantly increase, suggesting that the cells that are not arrested at medial nuclear division carry lesions (perhaps chromosome losses?) that limit cell division. Consistent with

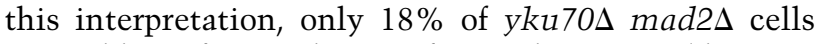
were able to form colonies after $18 \mathrm{~h}$ at $37^{\circ} \mathrm{C}$ (data not shown).

Why should cells with damaged telomeres activate spindle checkpoint pathways? One explanation is that cells with damaged telomeres generate telomere fusions and dicentric chromosomes at high rates. Indeed, it is known that mammalian cells lacking $\mathrm{Ku}$ suffer from 
Table 1. Yeast strains

\begin{tabular}{|c|c|c|}
\hline DLY & Genotype & Origin \\
\hline 640 & Mata ade2-1 trp1-1 can1-100 leu2-3,112 his3-11,15 ura3 GAL+ psi+ ssd1-d2 RAD5 & R. Rothstein \\
\hline 641 & MATalpha ada2-1 trp1-1 can1-100 leu2-3,112 his3-11,15 ura3 GAL+ psi+ ssd1-d2 RAD5 & R. Rothstein \\
\hline 883 & MATa ddc1::KanMX4 rad5-535 & M.P. Longhese \\
\hline 974 & MATa yku70::HIS3 RAD5 rDNA::ADE2 & L. Guarente \\
\hline 1028 & MATalpha yku70::LEU2 rad5-535 & S. Jackson \\
\hline 1095 & MATa chk1::HIS3 RAD5 & 640 transformation \\
\hline 1199 & MATa yku70::HIS3 rad17::LEU2 rad5-535 & $974 \times 607$ \\
\hline 1208 & MATalpha yku70::LEU2 mec3::TRP1 rad5-535 & $886 \times 1028$ \\
\hline 1209 & MATa yku70::LEU2 mec3::TRP1 rad5-535 & $886 \times 1028$ \\
\hline 1210 & MATa ddc1::KanMX4 yku70::LEU2 rad5-535 & $886 \times 1028$ \\
\hline 1211 & MAT alpha ddc1::KanMX4 yku70::LEU2 rad5-535 & $886 \times 1028$ \\
\hline 1214 & MATalpha yku70::LEU2 rad9::HIS3 rad24::TRP1 rad5-535 & $1028 \times 261$ \\
\hline 1215 & MATa yku70::LEU2 chk1::HIS3 RAD5 & $1028 \times 1096$ \\
\hline 1230 & Mata cdc13-1int RAD5 & 1108 transformation \\
\hline 1248 & MATa rad5-535 sml1:KANMX4 & M.P. Longhese \\
\hline 1249 & MATa rad5-535 sml1del::KANMX4 mec1::HIS3 & M.P. Longhese \\
\hline 1255 & MATa cdc13-1int rad9::HIS3 RAD5 & $662 \times 1218$ \\
\hline 1257 & MATa cdc13-1int rad24::TRP1 RAD5 & $662 \times 1218$ \\
\hline 1264 & MATalpha yku70::LEU2 rad9::HIS3 RAD5 & $1218 \times 1214$ \\
\hline 1266 & MAT a yku70::LEU2 chk1::HIS3 RAD5 & $1028 \times 1096$ \\
\hline 1271 & MATa yku70::LEU2 rad9::HIS3 RAD5 & $1264 \times 1285$ \\
\hline 1284 & MATa rad24::TRP1 yku70::HIS3 RAD5 & $974 \times 1258$ \\
\hline 1296 & MATa exo1::LEU2 cdc13-1int RAD5 & $1272 \times 1230$ \\
\hline 1312 & MATalpha yku70::LEU2 mec1::HIS3 rad5-535 sml1::KANMX4 & $1028 \times 1249$ \\
\hline 1325 & MATa yku70::LEU2 mec1::HIS3 rad5-535 sml1::KANMX4 & $1028 \times 1249$ \\
\hline 1327 & MATa yku70::LEU2 mec1::HIS3 rad24::TRP1 sml1del::KANMX4 & $1312 \times 1285$ \\
\hline 1337 & MATA yku70::LEU2 rad9::HIS3 rad24::TRP1 rad5-535 & $1028 \times 261$ \\
\hline 1347 & MATalpha yku70::HIS3 rad17::LEU2 RAD5 & $1308 \times 1284$ \\
\hline 1364 & MATa rad24::TRP1yku70::HIS3 RAD5 & $1308 \times 1284$ \\
\hline 1366 & MATalpha yku70::HIS3 RAD5 & $1308 \times 1284$ \\
\hline 1408 & MATa yku70::HIS3 exo1::LEU2 RAD5 & $1273 \times 1364$ \\
\hline 1409 & MATalpha yku70::HIS3 exo1::LEU2 RAD5 & $1273 \times 1364$ \\
\hline 1410 & MATalpha yku70::HIS3 exo1::LEU2 rad24::TRP1 RAD5 & $1273 \times 1364$ \\
\hline 1411 & MATa yku70::HIS3 exo1::LEU2 rad24::TRP1 RAD5 & $1273 \times 1364$ \\
\hline 1412 & MATa yku70::HIS3 RAD5 & $1273 \times 1364$ \\
\hline 1430 & MATa yku70::HIS3 rad24::TRP1 RAD5 & $1399 \times 1364$ \\
\hline 1439 & MATalpha bub2::URA3 yku70::LEU2 rad5-535 & $1429 \times 1371$ \\
\hline 1440 & MATalpha bub2::URA3 yku70::LEU2 RAD5 & $1429 \times 1371$ \\
\hline 1441 & MATalpha bub2::URA3 yku70::LEU2 rad24::TRP1 RAD5 & $1429 \times 1371$ \\
\hline 1442 & MATa bub2::URA3 yku70::LEU2 chk1::HIS3 rad5-535 & $1429 \times 1371$ \\
\hline 1443 & MATa bub2::URA3 yku70::LEU2 chk1::HIS3 rad24::TRP1 RAD5 & $1429 \times 1371$ \\
\hline 1445 & MATa mad2::URA3 yku70::LEU2 rad5-535 & $1429 \times 1372$ \\
\hline 1446 & MATa mad2::URA3 yku70::LEU2 chk1::HIS3 RAD5 & $1429 \times 1372$ \\
\hline 1448 & MATa mad2::URA3 yku70::LEU2 rad24::TRP1 RAD5 & $1429 \times 1372$ \\
\hline 1449 & MATalpha mad2::URA3 yku70::LEU2 rad24::TRP1RAD5 & $1429 \times 1372$ \\
\hline 1451 & MATalpha bub2::URA3 RAD5 & $1429 \times 1371$ \\
\hline 1496 & MATalpha cdc13-1int bub2::URA3 RAD5 & $1451 \times 1255$ \\
\hline 1497 & MATalpha cdc13-1int bub2::URA3 RAD5 & $1451 \times 1255$ \\
\hline 1498 & MATa cdc13-1int mad2::URA3 rad9::HIS3 RAD5 & $1452 \times 1255$ \\
\hline 1499 & MATalpha cdc13-1int mad2::URA3 rad9::HIS3 RAD5 & $1452 \times 1255$ \\
\hline 1500 & MATalpha cdc13-1int mad2::URA3 RAD5 & $1452 \times 1255$ \\
\hline 1501 & MATa cdc13-1int mad2::URA3 RAD5 & $1452 \times 1255$ \\
\hline 1502 & MATa cdc13-1int bub2::URA3 RAD5 rad9::HIS3 & $1451 \times 1255$ \\
\hline 1503 & MATalpha cdc13-1int bub2::URA3 RAD5 rad9::HIS3 & $1451 \times 1255$ \\
\hline 1505 & MATalpha yku70::LEU2 rad24::TRP1 RAD5 & $1429 \times 1371$ \\
\hline 1552 & MATa mad2::URA3 yku70::LEU2 & $1400 \times 1449$ \\
\hline 1553 & MATa dun1::HIS3 yku70::LEU2 & $1400 \times 1449$ \\
\hline 1554 & MATalpha dun1::HIS3 yku70::LEU2 & $1400 \times 1449$ \\
\hline 1676 & MATalpha mre11::hisG::URA3 exo1::LEU2 RAD5 & $1330 \times 1409$ \\
\hline 1678 & MATalpha yku70::HIS3 mre11::hisG::URA3 RAD5 & $1330 \times 1409$ \\
\hline 1679 & MATalpha yku70::HIS3 mre11::hisG::URA3 RAD5 & $1330 \times 1409$ \\
\hline 1680 & MATa yku70::HIS3 mre11::his G::URA3 exo1::LEU2 RAD5 & $1330 \times 1409$ \\
\hline 1746 & MATalpha mre11::hisG::URA3 RAD5 & $1330 \times 1409$ \\
\hline
\end{tabular}

The strains are in the W303 background and relevant genotypes are shown. Where strains are the products of a genetic cross, the numbers of parent strains are also indicated. 
high levels of telomere fusions (Bailey et al. 1999; Hsu et al. 2000; Samper et al. 2000; d'Adda di Fagagna et al. 2001). In yeast, it has been shown that dicentric chromosomes, a product of telomere fusion, are activators of both spindle and DNA damage checkpoint pathways (Neff and Burke 1992).

$5^{\prime}$ to $3^{\prime}$ exonucleases are thought to play a physiological role in the replication and stability of telomeres, but the nature of the exonuclease(s) responsible for telomere replication remains unclear (Wellinger et al. 1996; Diede and Gottschling 2001; Tsukamoto et al. 2001). We have shown that EXO1 but not MRE11 is required to generate

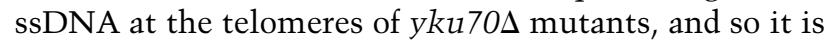
conceivable that EXO1 also plays a role in physiological metabolism of telomeres. MRE11, in contrast to EXO1, stablizes telomeres of yku70s mutants. If Exolp does play a role in the physiology of telomeres, then other exonucleases must function redundantly with Exolp because the telomeres of exo1s mutants appear normal (Tsubouchi and Ogawa 2000).

Defects in mismatch repair are associated with checkpoint defects in mammalian cells (Bellacosa 2001; Yan et al. 2001) and enhanced cellular proliferation of yeast cells that lack telomerase (Rizki and Lundblad 2001). Our demonstration that the mismatch repair-associated exonuclease, Exolp, affects the metabolism of damaged telomeres, and checkpoint responses, suggests a mechanism by which mismatch repair affects checkpoint control and tolerance of damaged telomeres.

\section{Materials and methods}

\section{Yeast strains}

All strains used in this study are isogenic and in the W303 background; in most cases we used RAD5 rather than rad5-535 strains (Fan et al. 1996), but we observed no effect of the rad5535 mutation in any experiments. To construct strains, standard genetic procedures of transformation and tetrad analysis were followed (Adams et al. 1997). Since W303 strains contain an ade2-1 mutation YEPD (yeast extract, peptone, and dextrose), the medium was routinely supplemented with adenine at $50 \mathrm{mg} / \mathrm{L}$. The yku70s deletion strains were obtained from L. Guarente (Massachusetts Institute of Technology, Cambridge, MA) and S. Jackson (University of Arizona, Tuscon, AZ). A chk1::HIS3 deletion was created using pYS51 (Sanchez et al. 1999). The mec1s and sml1s deletion strains were obtained from M.P. Longhese (Paciotti et al. 2000). An exo1::LEU2 disruption was constructed using pHT246 and an mre::hisg::URA3 deletion with pHT16 (Tsubouchi and Ogawa 2000). mad2s and bub2s deletion strains were obtained from L Dirick. Dun1s strains were obtained from $\mathrm{T}$. Weinert. Other deletions have been described elsewhere (Lydall and Weinert 1997). cdc13-1int strains contain a $c d c 13-1$ integrated allele rather than one that was introduced by backcrossing from the A364a genetic background.

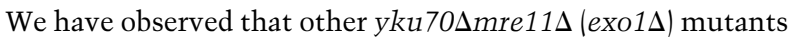
enter crisis after several generations, and therefore we assume the strains analysed in Figure 7 have escaped or avoided crisis.

\section{Serial dilution and growth on plates}

Colony-purified yeast strains were inoculated into $1 \mathrm{~mL}$ YEPD (ade), and grown overnight with aeration. In the morning, cultures were diluted 1:10, grown for about $4 \mathrm{~h}$, sonicated, counted by hemocytometer, and diluted to $1.5 \times 10^{7}$ cells $/ \mathrm{mL}$. Fivefold dilution series were set up in 96-well plates, and small aliquots of the dilution series were transferred to YEPD (ade) plates using metal prongs. Plates were incubated for $2 \mathrm{~d}$ before being photographed.

\section{Liquid culture, medial nuclear division, and viability assays}

Single purified colonies were inoculated directly into $50 \mathrm{~mL}$ of YEPD (ade) and cultured overnight, with aeration, at $23^{\circ} \mathrm{C}$. In the morning, cell densities were determined by hemocytometer, and cultures were diluted to $2 \times 10^{6}$ cells $/ \mathrm{mL}\left(1 \times 10^{8}\right.$ cells in $50 \mathrm{~mL}$, or $0.4 \times 10^{8}$ cells in $20 \mathrm{~mL}$ ). The cultures were placed at the restrictive temperature of $37^{\circ} \mathrm{C}$, and samples were taken at the times indicated. Cultures were maintained at a concentration that allowed exponential growth, diluting when necessary with prewarmed $\left(37^{\circ} \mathrm{C}\right)$ medium. Cell densities were determined by hemocytometer, and the corrected cell number was calculated as a product of cell density and cumulative dilution factor. To score checkpoint arrest, samples were taken at the indicated time points and fixed in $70 \% \mathrm{EtOH}$, then washed twice with water. To visualize the DNA, cells were resuspended in $0.2 \mu \mathrm{g} / \mathrm{mL} 4^{\prime} 6^{\prime}$-diamidino-2 phenylindole (DAPI), sonicated, and examined by fluorescent microscopy. At least 200 cells were counted using the multicounter, and classified as described previously (Gardner et al. 1999) as: (1) unbudded, single DAPI-stained body; (2) small budded, single DAPI-stained body, the bud $<50 \%$ of the diameter of the mother cell; (3) medial nuclear division, single DAPI-stained body, bud $>50 \%$ diameter of mother cell; and (4) late nuclear division, two buds, and two DAPI-stained bodies, and (5) none of these types.

\section{Microcolony assays}

Colony-purified yeast strains were inoculated into $1 \mathrm{~mL}$ YEPD (ade), grown overnight with aeration, at the appropriate temperature $\left(20^{\circ} \mathrm{C}\right.$ for $c d c 13-1$ strains and $23^{\circ} \mathrm{C}$ for yku70s cells), until they reached a concentration of about $8 \times 10^{6}$ cells $/ \mathrm{mL}$. Cells were arrested in G1 with alpha-factor for about $2.5 \mathrm{~h}$, and arrest was monitored microscopically. Arrested cells were washed twice with YEPD (ade), sonicated briefly, and spread on plates. The plates were incubated at the indicated temperature. After an appropriate length of time the colonies were photographed.

\section{Single-stranded DNA measurements}

Single-stranded DNA was measured as described (Booth et al. 2001) except that we calculated ssDNA levels by comparison with a PDA1 "loading control." PDA1 is $30 \mathrm{kbp}$ from the telomere and does not become single-stranded in yku70D mutants. The PDA1 and YER188W primers are as described (Booth et al. 2001). The sequences of the primers used to detect ssDNA in the $\mathrm{Y}^{\prime}$ sequence are available on request.

\section{Acknowledgments}

We thank L. Dirick, S. Elledge, H. Ogawa, S. Jackson, L. Guarente, M.P.Longhese, V. Lundblad, S. Piatti, R. Rothstein, Y. Sanchez, L. Symington, H. Tsubouchi, and T. Weinert for plasmids, protocols, or yeast strains. We thank all members of our 
lab, Keith Caldecott, and Elspeth Stewart for comments on the manuscript. L.M. was partially supported by the Vorarlberger Landesregierung. D.L. is a Wellcome Senior Research Fellow in Basic Biomedical Science.

The publication costs of this article were defrayed in part by payment of page charges. This article must therefore be hereby marked "advertisement" in accordance with 18 USC section 1734 solely to indicate this fact.

\section{References}

Adams, A., Gottshcling, D.E., Kaiser, C.A., and Stearns, T. 1997. Methods in yeast genetics. pp. 131-132. Cold Spring Harbor Laboratory Press, New York.

Bailey, S.M., Meyne, J., Chen, D.J., Kurimasa, A., Li, G.C., Lehnert, B.E., and Goodwin, E.H. 1999. DNA double-strand break repair proteins are required to cap the ends of mammalian chromosomes. Proc. Natl. Acad. Sci. 96: 1489914904.

Barnes, G. and Rio, D. 1997. DNA double-strand-break sensitivity, DNA replication, and cell cycle arrest phenotypes of Ku-deficient Saccharomyces cerevisiae. Proc. Natl. Acad. Sci. 94: 867-872.

Bellacosa, A. 2001. Functional interactions and signaling properties of mammalian DNA mismatch repair proteins. Cell Death Differ. 8: 1076-1092.

Bishop, D.K., Park, D., Xu, L., and Kleckner, N. 1992. DMC1: A meiosis-specific yeast homolog of E. coli recA required for recombination, synaptonemal complex formation, and cell cycle progression. Cell 69: 439-456.

Booth, C., Griffith, E., Brady, G., and Lydall, D. 2001. Quantitative amplification of single-stranded DNA (QAOS) demonstrates that cdc13-1 mutants generate ssDNA in a telomere to centromere direction. Nucleic Acids Res. 29: 4414-4422.

Boulton, S.J. and Jackson, S.P. 1996. Identification of a Saccharomyces cerevisiae Ku80 homologue: Roles in DNA double strand break rejoining and in telomeric maintenance. Nucleic Acids Res. 24: 4639-4648.

. 1998. Components of the Ku-dependent non-homologous end-joining pathway are involved in telomeric length maintenance and telomeric silencing. $E M B O \quad J$. 17: $1819-1828$.

Caspari, T. and Carr, A.M. 2002. Checkpoints: How to flag up double-strand breaks. Curr. Biol. 12: R105-R107.

d'Adda di Fagagna, F., Hande, M.P., Tong, W., Roth, D., Lansdorp, P.M., Wang, Z., and Jackson, S.P. 2001. Effects of DNA nonhomologous end-joining factors on telomere length and chromosomal stability in mammalian cells. Curr. Biol. 11: 1192-1196.

Diede, S.J. and Gottschling, D.E. 2001. Exonuclease activity is required for sequence addition and $\mathrm{Cdc} 13 \mathrm{p}$ loading at a de novo telomere. Curr. Biol. 11: 1336-1340.

Fan, H.Y., Cheng, K.K., and Klein, H.L. 1996. Mutations in the RNA polymerase II transcription machinery suppress the hyperrecombination mutant hprl delta of Saccharomyces cerevisiae. Genetics 142: 749-759.

Feldmann, H. and Winnacker, E.L. 1993. A putative homologue of the human autoantigen $\mathrm{Ku}$ from Saccharomyces cerevisiae. J. Biol. Chem. 268: 12895-12900.

Fellerhoff, B., Eckardt-Schupp, F., and Friedl, A.A. 2000. Subtelomeric repeat amplification is associated with growth at elevated temperature in yku70 mutants of Saccharomyces cerevisiae. Genetics 154: 1039-1051.

Gardner, R.D. and Burke, D.J. 2000. The spindle checkpoint: Two transitions, two pathways. Trends Cell Biol. 10: 154158
Gardner, R., Putnam, C.W., and Weinert, T. 1999. RAD53, DUN1 and PDS1 define two parallel G(2)/M checkpoint pathways in budding yeast. EMBO J. 18: 3173-3185.

Garner, M., van Kreeveld, S., and Su, T.T. 2001. mei-41 and bub1 block mitosis at two distinct steps in response to incomplete DNA replication in Drosophila embryos. Curr. Biol. 11: 1595-1599.

Garvik, B., Carson, M., and Hartwell, L. 1995. Single-stranded DNA arising at telomeres in cdc13 mutants may constitute a specific signal for the RAD9 checkpoint. Mol. Cell. Biol. 15: 6128-6138.

Gilbert, C.S., Green, C.M., and Lowndes, N.F. 2001. Budding yeast $\mathrm{Rad} 9$ is an ATP-dependent Rad53 activating machine. Mol. Cell 8: 129-136.

Gravel, S., Larrivee, M., Labrecque, P., and Wellinger, R.J. 1998. Yeast $\mathrm{Ku}$ as a regulator of chromosomal DNA end structure. Science 280: 741-744.

Green, C.M., Erdjument-Bromage, H., Tempst, P., and Lowndes, N.F. 2000. A novel $\operatorname{Rad} 24$ checkpoint protein complex closely related to replication factor C. Curr. Biol. 10: 39-42.

Hartwell, L.H. 1974. Saccharomyces cerevisiae cell cycle. Bacteriol. Rev. 38: 164-198.

Hsu, H.L., Gilley, D., Galande, S.A., Hande, M.P., Allen, B., Kim, S.H., Li, G.C., Campisi, J., Kohwi-Shigematsu, T., and Chen, D.J. 2000. Ku acts in a unique way at the mammalian telomere to prevent end joining. Genes \& Dev. 14: 28072812.

Hu, F., Wang, Y., Liu, D., Li, Y., Qin, J., and Elledge, S.J. 2001. Regulation of the Bub2/Bfa1 GAP complex by Cdc5 and cell cycle checkpoints. Cell 107: 655-665.

Hwang, L.H., Lau, L.F., Smith, D.L., Mistrot, C.A., Hardwick, K.G., Hwang, E.S., Amon, A., and Murray, A.W. 1998. Budding yeast Cdc20: A target of the spindle checkpoint. Science 279: $1041-1044$

Laroche, T., Martin, S.G., Gotta, M., Gorham, H.C., Pryde, F.E., Louis, E.J., and Gasser, S.M. 1998. Mutation of yeast Ku genes disrupts the subnuclear organization of telomeres. Curr. Biol. 8: 653-656.

Lee, H., Trainer, A.H., Friedman, L.S., Thistlethwaite, F.C., Evans, M.J., Ponder, B.A., and Venkitaraman, A.R. 1999. Mitotic checkpoint inactivation fosters transformation in cells lacking the breast cancer susceptibility gene, Brca2. Mol. Cell 4: 1-10.

Lee, S.E., Moore, J.K., Holmes, A., Umezu, K., Kolodner, R.D., and Haber, J.E. 1998. Saccharomyces Ku70, Mre11/Rad50, and RPA proteins regulate adaptation to G2/M arrest after DNA damage. Cell 94: 399-409.

Lewis, L.K., Karthikeyan, G., Westmoreland, J.W., and Resnick, M.A. 2002. Differential suppression of DNA repair Deficiencies of yeast rad50, mre11 and xrs2 mutants by EXO1 and TLC1 (the RNA component of telomerase). Genetics 160: $49-62$.

Lowndes, N.F. and Murguia, J.R. 2000. Sensing and responding to DNA damage. Curr. Opin. Genet. Dev. 10: 17-25.

Lydall, D. and Weinert, T. 1995. Yeast checkpoint genes in DNA damage processing: Implications for repair and arrest. Science 270: 1488-1491.

- 1997. G2/M checkpoint genes of Saccharomyces cerevisiae: Further evidence for roles in DNA replication and/or repair. Mol. Gen. Genet. 256: 638-651.

Lydall, D., Nikolsky, Y., Bishop, D.K., and Weinert, T. 1996. A meiotic recombination checkpoint controlled by mitotic checkpoint genes. Nature 383: 840-843.

Martin, S.G., Laroche, T., Suka, N., Grunstein, M., and Gasser S.M. 1999. Relocalization of telomeric Ku and SIR proteins in response to DNA strand breaks in yeast. Cell 97: 621-633. 
Mishra, K. and Shore, D. 1999. Yeast Ku protein plays a direct role in telomeric silencing and counteracts inhibition by rif proteins. Curr. Biol. 9: 1123-1126.

Moreau, S., Morgan, E.A., and Symington, L.S. 2001. Overlapping functions of the Saccharomyces cerevisiae Mre11, Exo1 and $\operatorname{Rad} 27$ nucleases in DNA metabolism. Genetics 159: 1423-1433.

Neff, M.W. and Burke, D.J. 1992. A delay in the Saccharomyces cerevisiae cell cycle that is induced by a dicentric chromosome and dependent upon mitotic checkpoints. Mol. Cell Biol. 12: 3857-3864.

Nugent, C.I., Bosco, G., Ross, L.O., Evans, S.K., Salinger, A.P., Moore, J.K., Haber, J.E., and Lundblad, V. 1998. Telomere maintenance is dependent on activities required for end repair of double-strand breaks. Curr. Biol. 8: 657-660.

Paciotti, V., Clerici, M., Lucchini, G., and Longhese, M.P. 2000 The checkpoint protein Ddc2, functionally related to $\mathrm{S}$. pombe $\operatorname{Rad} 26$, interacts with Mec1 and is regulated by Mec1dependent phosphorylation in budding yeast. Genes \& Dev. 14: 2046-2059.

Pellicioli, A., Lucca, C., Liberi, G., Marini, F., Lopes, M., Plevani, P., Romano, A., DiFiore, P.P., and Foiani, M. 1999. Activation of Rad53 kinase in response to DNA damage and its effect in modulating phosphorylation of the lagging strand DNA polymerase. EMBO I. 18: 6561-6572.

Peterson, S.E., Stellwagen, A.E., Diede, S.J., Singer, M.S., Haimberger, Z.W., Johnson, C.O., Tzoneva, M., and Gottschling, D.E. 2001. The function of a stem-loop in telomerase RNA is linked to the DNA repair protein Ku. Nat. Genet. 27: 64-67.

Polotnianka, R.M., Li, J., and Lustig, A.J. 1998. The yeast Ku heterodimer is essential for protection of the telomere against nucleolytic and recombinational activities. Curr. Biol. 8: 831-834.

Porter, S.E., Greenwell, P.W., Ritchie, K.B., and Petes, T.D. 1996. The DNA-binding protein Hdflp (a putative Ku homologue) is required for maintaining normal telomere length in Saccharomyces cerevisiae. Nucleic Acids Res. 24: 582-585.

Pryde, F.E. and Louis, E.J. 1999. Limitations of silencing at native yeast telomeres. EMBO J. 18: 2538-2550.

Rizki, A. and Lundblad, V. 2001. Defects in mismatch repair promote telomerase-independent proliferation. Nature 411: 713-716.

Roeder, G.S. and Bailis, J.M. 2000. The pachytene checkpoint. Trends Genet. 16: 395-403.

Samper, E., Goytisolo, F.A., Slijepcevic, P., van Buul, P.P., and Blasco, M.A. 2000. Mammalian Ku86 protein prevents telomeric fusions independently of the length of TTAGGG repeats and the G-strand overhang. EMBO Rep. 1: 244-252.

Sanchez, Y., Bachant, J., Wang, H., Hu, F., Liu, D., Tetzlaff, M., and Elledge, S.J. 1999. Control of the DNA damage checkpoint by chk1 and rad53 protein kinases through distinct mechanisms. Science 286: 1166-1171.

Sandell, L.L. and Zakian, V.A. 1993. Loss of a yeast telomere: Arrest, recovery, and chromosome loss. Cell 75: 729-739.

Smith, G.C. and Jackson, S.P. 1999. The DNA-dependent protein kinase. Genes \& Dev. 13: 916-934.

Teo, S.H. and Jackson, S.P. 2001. Telomerase subunit overexpression suppresses telomere-specific checkpoint activation in the yeast yku80 mutant. EMBO Rep 2: 197-202.

Tishkoff, D.X., Boerger, A.L., Bertrand, P., Filosi, N., Gaida, G.M., Kane, M.F., and Kolodner, R.D. 1997. Identification and characterization of Saccharomyces cerevisiae EXO1, a gene encoding an exonuclease that interacts with MSH2. Proc. Natl. Acad. Sci. 94: 7487-7492.

Tsubouchi, H. and Ogawa, H. 2000. Exol roles for repair of DNA double-strand breaks and meiotic crossing over in Sac- charomyces cerevisiae. Mol. Biol. Cell 11: 2221-2233.

Tsukamoto, Y., Taggart, A.K., and Zakian, V.A. 2001. The role of the Mre11-Rad50-Xrs2 complex in telomerase-mediated lengthening of Saccharomyces cerevisiae telomeres. Curr. Biol. 11: 1328-1335.

Venclovas, C. and Thelen, M.P. 2000. Structure-based predictions of Rad1, Rad9, Hus1 and Rad17 participation in sliding clamp and clamp-loading complexes. Nucleic Acids Res. 28: 2481-2493.

Venkitaraman, A.R. 2002. Cancer susceptibility and the functions of BRCA1 and BRCA2. Cell 108: 171-182.

Wang, Y., Hu, F., and Elledge, S.J. 2000. The Bfa1/Bub2 GAP complex comprises a universal checkpoint required to prevent mitotic exit. Curr. Biol. 10: 1379-1382.

Weinert, T.A. and Hartwell, L.H. 1993. Cell cycle arrest of cdc mutants and specificity of the RAD9 checkpoint. Genetics 134: 63-80.

Weinert, T.A., Kiser, G.L., and Hartwell, L.H. 1994. Mitotic checkpoint genes in budding yeast and the dependence of mitosis on DNA replication and repair. Genes \& Dev. 8: 652-665.

Wellinger, R.J., Ethier, K., Labrecque, P., and Zakian, V.A. 1996. Evidence for a new step in telomere maintenance. Cell 85: 423-433.

Yan, T., Schupp, J.E., Hwang, H.S., Wagner, M.W., Berry, S.E., Strickfaden, S., Veigl, M.L., Sedwick, W.D., Boothman, D.A., and Kinsella, T.J. 2001. Loss of DNA mismatch repair imparts defective cdc2 signaling and G(2) arrest responses without altering survival after ionizing radiation. Cancer Res. 61: 8290-8297. 


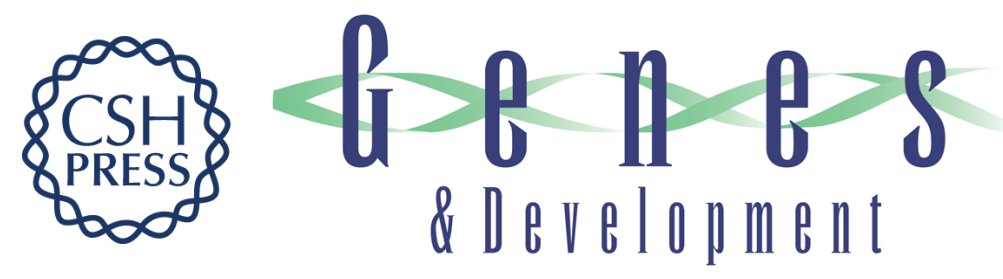

\section{EXO1-dependent single-stranded DNA at telomeres activates subsets of DNA damage and spindle checkpoint pathways in budding yeast yku70 $\Delta$ mutants}

Laura Maringele and David Lydall

Genes Dev. 2002, 16:

Access the most recent version at doi:10.1101/gad.225102

References This article cites 60 articles, 27 of which can be accessed free at:

http://genesdev.cshlp.org/content/16/15/1919.full.html\#ref-list-1

License

Email Alerting

Receive free email alerts when new articles cite this article - sign up in the box at the top

Service

right corner of the article or click here.

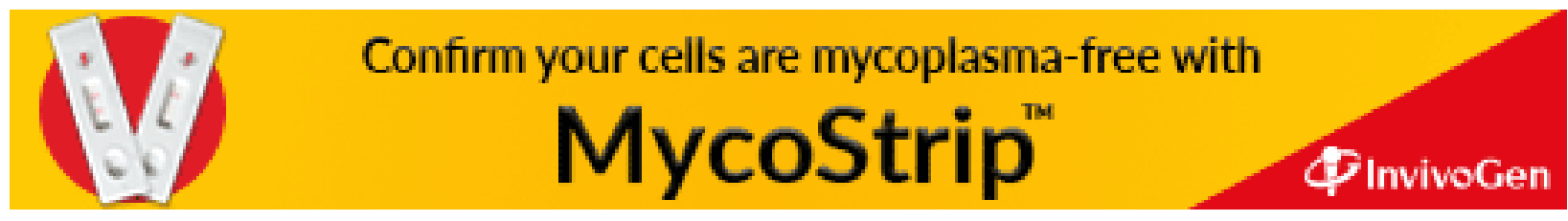

